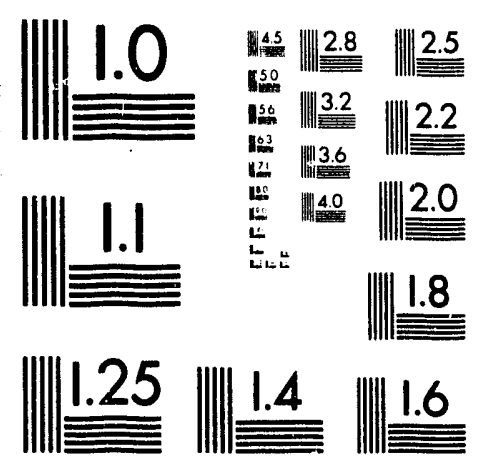



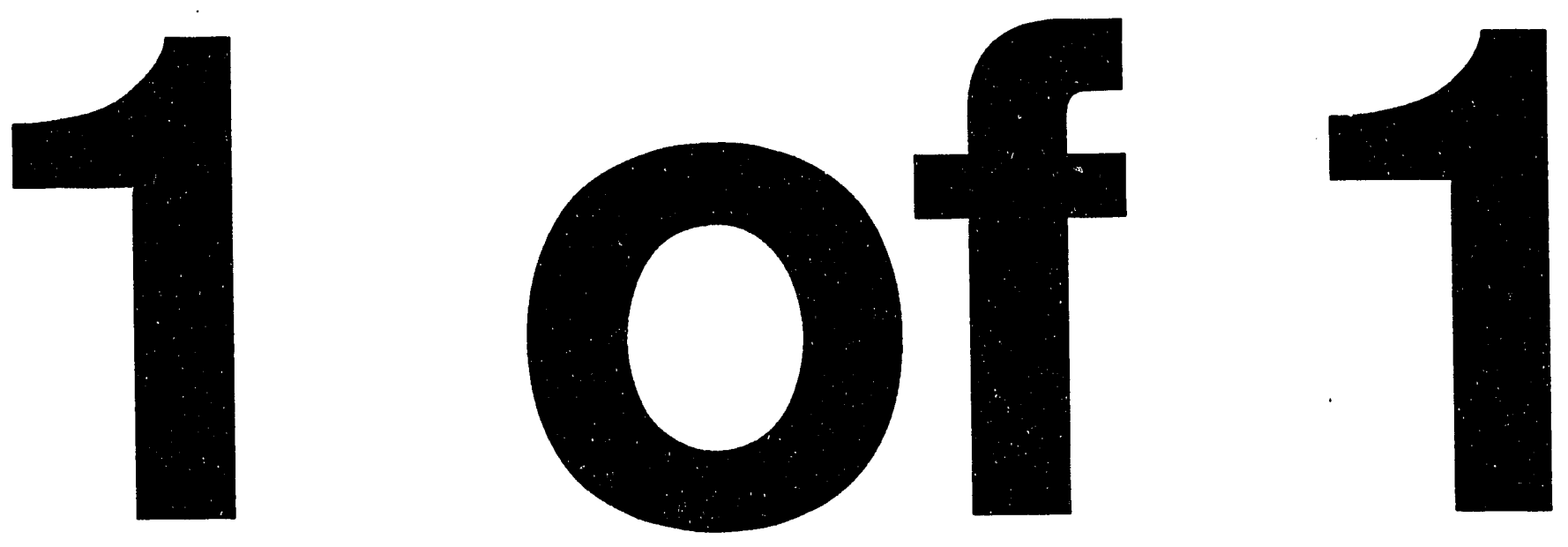


\section{Geophysical Study of the Building 103 Dump, Aberdeen Proving Ground}

by L.D. McGinnis, S.F. Miller, M.D. Thompson, and M.G. McGinnis

Reclamation Engineering and Geosciences Section, Energy Systems Division, Argonne National Laboratory, 9700 South Cass Avenue, Argonne, Illinois 60439

Work sponsored by United States Department of Defense, United States Army, Aberdeen Proving Ground, Maryland 
This document is printed on recycled paper with the exception of color reproductions. 


\section{Preface}

This report is one of a series on geophysical surveys around perimeters of buildings in the Canal Creek and Westwood areas of the Edgewood section of Aberdeen Proving Ground. The series was initiated in 1991 at Building E5032, where geophysical techniques were tested and a design for the surveys was established. The series continued in 1992, when surveys of Buildings E5190, E5282, E5375, E5440, E5476, E5481, E5485, E5487, E5489, E5974, and E5978 were completed. The surveys and reports were done sequentially, with lowest building numbers being completed first. For this reason, deeper insight into the magnetic, electrical, and radar imagery characteristics of the Canal Creek area was gained with progressively increasing building numbers. A survey at the Building 103 Dump, also completed during the spring of 1992 , was not specifically designed to assist building decommissioning, but it is included in the series because it

was conducted by our geophysics team using techniques and procedures identical to those for the building decommissioning surveys. 


\section{Contents}

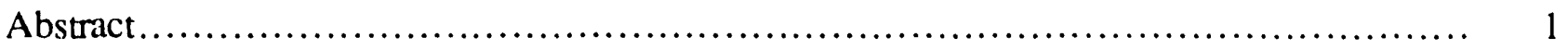

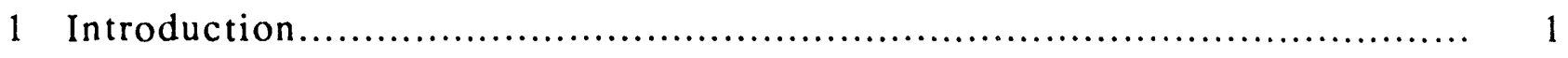

1.1 History of the Building 103 Dump................................... 4

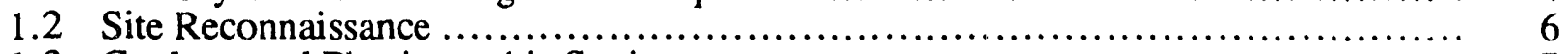

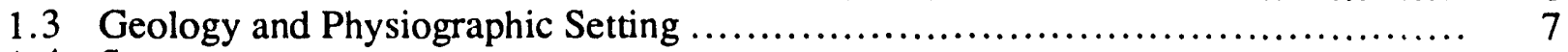

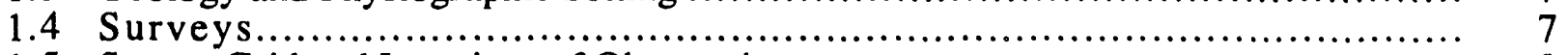

1.5 Survey Grid and Locations of Observations $\ldots \ldots \ldots \ldots \ldots \ldots \ldots \ldots \ldots \ldots \ldots \ldots \ldots$

2 Instrumentation ............................................................ 10

2.1 Magnetic Gradiometer and Cable Locator..................................... 10

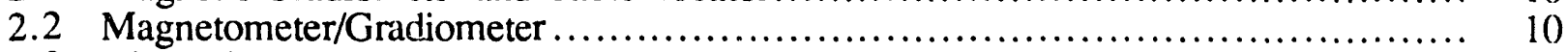

2.3 Direct-Current Electrical Resistivity Meter .................................... 11

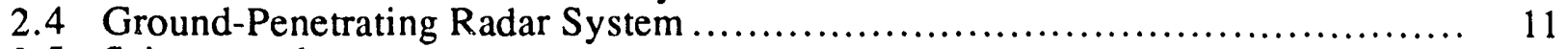

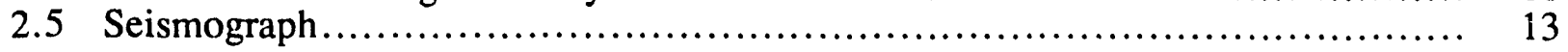

3 Geophysical Measurements and Surveys ...................................... 14

3.1 Magnetometer Measurements ........................................... 14

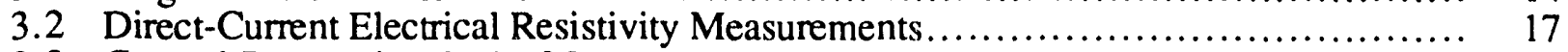

3.3 Ground-Penetrating Radar Measurements ........................................ 17

3.4 Seismic Refraction Measurements $\ldots \ldots \ldots \ldots \ldots \ldots \ldots \ldots \ldots \ldots \ldots \ldots \ldots \ldots \ldots \ldots .20$

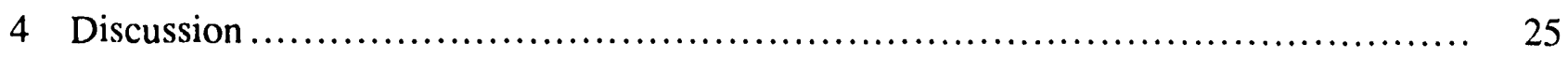

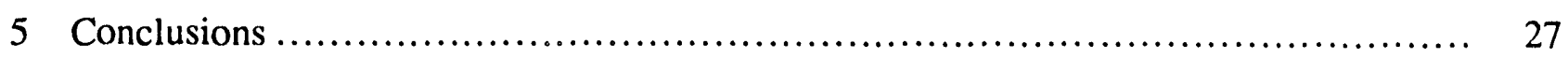

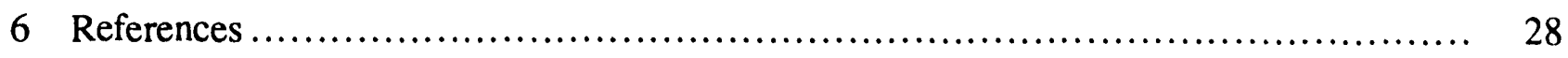

Appendix A: Electrical Depth-Sounding Curves.................................... 31

Appendix B: Ground-Penetrating Radar Line Coordinates ............................ 39

\section{Tables}

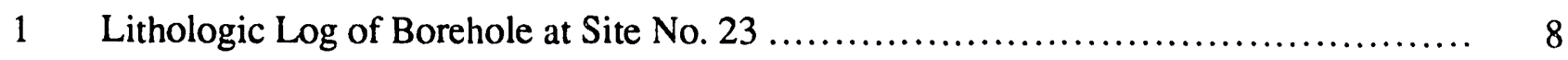

2 Approximate Two-Way Travel Times for Various Materials....................... 12

A.1 Location of Centers of Stations and Orientations of Electrode Arrays for Schlumberger Electrical Depth Soundings at APG . 


\section{Figures}

1 General Site Map of the Canal Creek Area, Aberdeen Proving Ground, Md. ........... 2

2 Geophysical Survey Boundary for the Building 103 Dump............................ 3

3 Lithologic Log of Borehole No. 23 near the South Margin of the Building 103 Dump and the Seismic Correlation ............................................ 9

4 Map of Total Magnetic-Field Intensity for the Building 103 Dump Plotted from Measurements Made with the Sensor on the Ground ............................. 15

5 Map of Total Magnetic-Field Intensity for the Building 103 Dump Plotted from Measurements Made with the Sensor Elevated $8 \mathrm{ft}$ above the Ground................ 16

6 Map of Apparent Resistivity for the Building 103 Dump......................... 18

7 West-East Ground-Penetrating Radar Profile of the Building 103 Dump (a) along the Southern Boundary and (b) through the Central Part of the Survey Area ...... 19

8 Seismic Refraction Time-Distance Curves at the Building 103 Dump ................ 21

9 Interpretation of Seismic Spread for APG1 at the Building 103 Dump ............... 22

10 Magnetics/Resistivity Overlay Map of the Building 103 Dump with the Magnetics Data Measured with the Sensor on the Ground ................................ 24

11 Magnetics/Resistivity Overlay Map of the Building 103 Dump with the Magnetics Data Measured with the Sensor Elevated $8 \mathrm{ft}$ above the Ground......................... 26

A.1 Electrical Depth-Sounding Curve near Building E5282 ...................... 35

A.2 Electrical Depth-Sounding Curve near Building E5440..................... 36

A.3 Electrical Depth-Sounding Curve near Building E5481 ..................... 37

A.4 Electrical Depth-Sounding Curve near Building E5974...................... 38 


\title{
Geophysical Study of the Building 103 Dump, Aberdeen Proving Ground
}

\author{
by \\ L.D. McGinnis, S.F. Miller, \\ M.D. Thompson, and M.G. McGinnis
}

\begin{abstract}
The Building 103 Dump is one of ten potentially contaminated sites in the Canal Creek and Westwood areas of the Edgewood section of Aberdeen Proving Ground examined by a geophysical team from Argonne National Laboratory in April and May of 1992. Noninvasive geophysical surveys, including magnetics, resistivity, ground-penetrating radar, and seismic refraction, were conducted. These surveys indicate that much of the area is free of debris. However, prominent magnetic and resistivity anomalies occur along well-defined lineaments, suggestive of a dendritic stream pattern. Prior to the onset of dumping, the site was described as a "sand pit," which suggests that headward erosion of Canal Creek tributaries cut into the surficial aquifer. Contaminants dumped into the landfill would have direct access to the surficial aquifer and thus to Canal Creek. Seismic refraction profiling indicates 6-12 ft of fill material now rests on the former land surface. Only the northern third of the former landfill was geophysically surveyed.
\end{abstract}

\section{Introduction}

Aberdeen Proving Ground (APG), in the state of Maryland, is currently managing a comprehensive Installation Restoration Program involving over 360 solid-waste managing units contained within 13 study areas. The Edgewood area (EA) and two landfills at APG are on the National Priority List under the Comprehensive Environmental Response, Compensation, and Liability Act. Therefore, APG has entered into an interagency agreement with the U.S. Environmental Protection Agency to address the listed areas.

The Canal Creek area (Figure 1) is one of the areas that requires a Source Definition Study because of an ongoing release of volatile organic compounds into the creek. The Building 103 Dump (Figure 2), located on the southwest corner of the intersection of Hoadley and Williams Roads, is in the West Branch of Canal Creek area and is a potential source of volatile organic compounds. Operations in the landfill have ceased. 


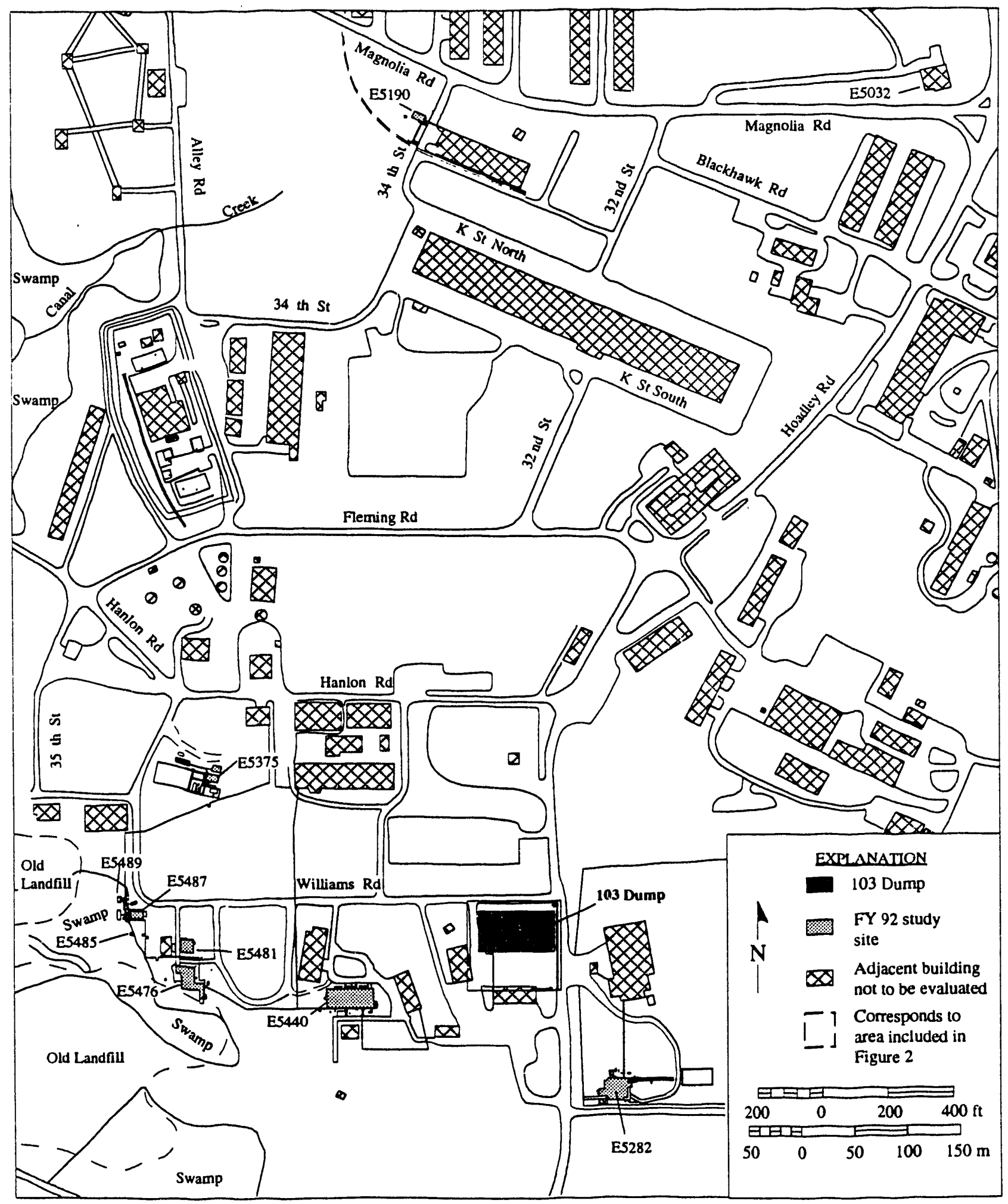

FIGURE 1 General Site Map of the Canal Creek Area, Aberdeen Proving Ground, Md. 

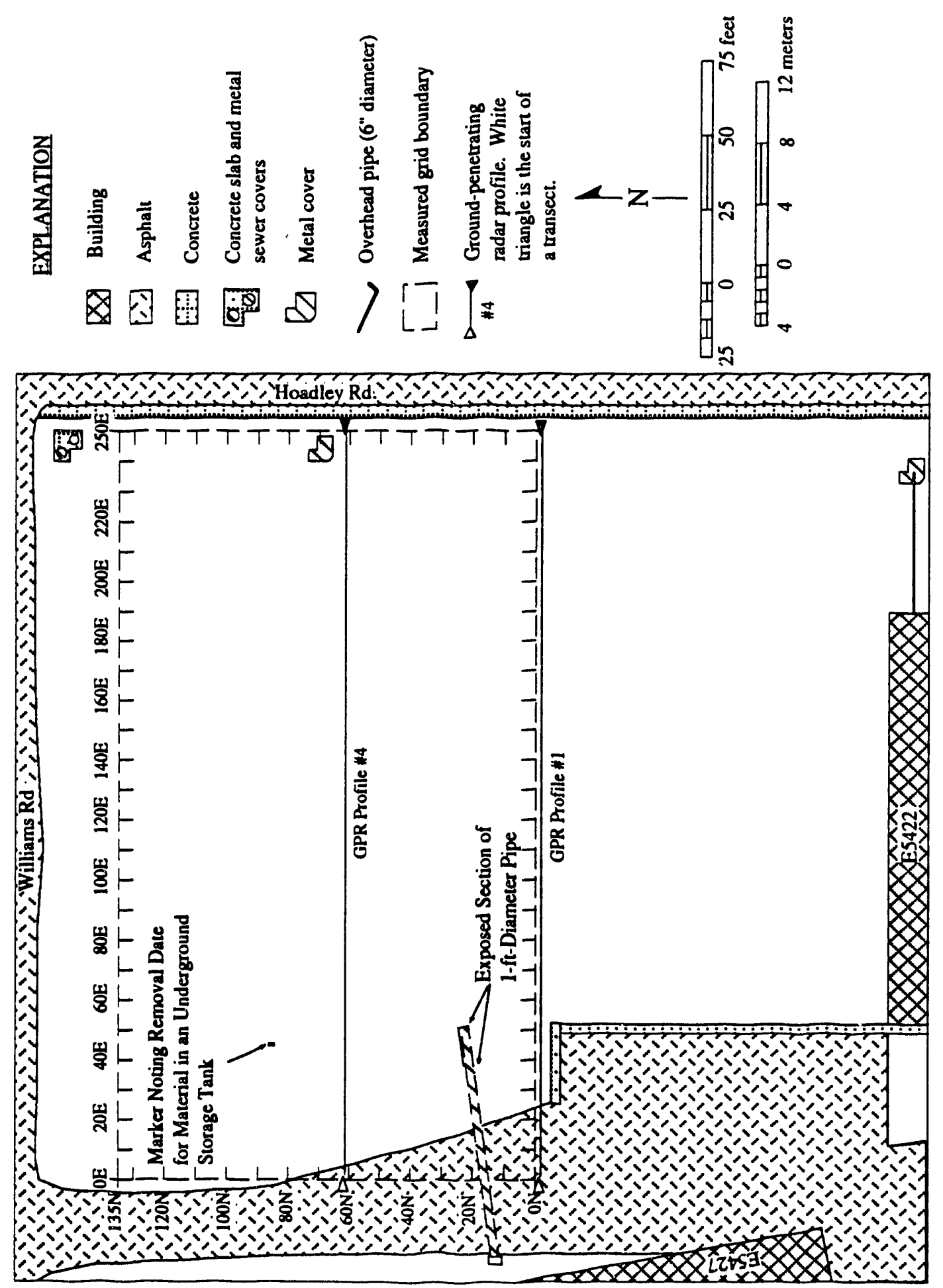

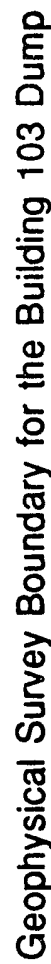

N

$\frac{w}{\frac{\pi}{5}}$ 


\subsection{History of the Building 103 Dump}

Information on the history of the Building 103 Dump is taken from the Resource Conservation and Recovery Act (RCRA) Facility Assessment Report, Edgewood Area, Aberdeen Proving Ground, Maryland (AEHA 1989). The verbatim report follows:

The Building 103 Dump is located immediately southwest of the intersection of Hoadley Road and Williams Road in the old chemical plants area of APG-EA. The site is referred to as the Building 103 Dump because old Building 103 (E5385) was located immediately north of the dump.

This SWMU [Solid Waste Management Unit] is a former waste dumping and burial site. The site was originally a sand pit, which was used during WWI [World War I] when the chemical and filling plants were constructed at APG-EA. After WWI, the sand pit became a dump site for miscellaneous wastes including junk and possibly chemicals. The Building 103 Dump was used as a disposal site until the late 1930s or early 1940s. Ground scarring at the site is visible in 1929 and 1938 photographs. The ground scar area probably included both the pit and the working area around the pit. Building 655 (E5422) is shown as being within the area of the dump, but was probably not actually built on the dump, but rather within the area of activity around the pit. Note: Building 655 was constructed in 1942 as a change house and is today the headquarters building for the U.S. Army Technical Escort Unit.

The Building 103 Dump, including working area around the pit, was about 320 feet from north to south, 280 feet from east to west, and occupied an area of approximately 1.7 acres.

The only reference to the Building 103 Dump in a document is a "Diary" of Edgewood Arsenal [USAEA 1946] in which there is a 6 April 1937 entry, "The DUMP AREA south of S1 Building was filled in and the land policed this date." Later aerial photographs, as late as 1964 , continue to show ground scarring in the area of the former dump, but this is believed to be the result of activities in the area other than burial. Information from interviews concerning the Building 103 Dump is also very limited. One interviewee [Gaunt], who worked at Edgewood Arsenal from 1919 to 1960, remembers the pit being used prior to the early 1940s. Gaunt remembers that use of the pit included disposal of three mustard storage tanks, still containing some mustard and sulfur sludge. Gaunt also stated that some ordnance may have been disposed of in the pit. Other interviewees also remember use of the Building 103 dump during the early 1940s, including trucks being disposed of in the pit and material being removed from the site as part of cleanup. It is likely that the site was used for dumping prior to 1937; that cleanup, including burial, was accomplished in 1937; that use of the site as a dump continued into the early 1940s; and that little or no burial occurred after 1943 or 1944. 
There is almost no information available concerning the amount of chemical wastes placed into the Building 103 Dump. It is possible that the unit was used mainly for unserviceable equipment and other junk, and that chemical wastes were disposed of in other locations, such as the Canal Creek marsh. It is not known if the mustard tanks placed into the pit were later removed. It is known that several mustard tanks were placed into Old O-field during the early or mid 1940s, when cleanup at the Building 103 Dump may have occurred. Inspection of the site reveals erosion of cover soil into the fill material at some locations, mainly in the northern part of the site. At one location in the northwest portion of the pit, a tank is visible near the surface. The tank has been sampled by CRDEC [Chemical Research, Development, and Engineering Center] and found to be partially filled with a mixture of organic chemicals, with the greatest portion being bromobenzylcyanide.

When the Whetlerite plant in Building 619 was operated during the 1948 to 1952 period, scrap wire was used as a source of copper. The insulation was removed from the scrap copper wire by burning, which was accomplished in the open area which had been the Building 103 Dump/Pit. It is not known if similar burning was accomplished in the area during other periods of time.

The ground surface elevation in the Building 103 Dump site ranges from approximately 20 to $30 \mathrm{ft}$ above msl [mean sea levell. Surface water runoff from the site is to the south-southeast, with drainage out of the site flowing between Building 655 and Hoadley Road, south in a ditch along the west side of Hoadley Road for a short distance, and then into the stormwater sewer system which discharges into the east Branch of Canal Creek. As part of RFI [RCRA Facility Investigation] work, the USGS [U.S. Geological Survey] has installed two monitoring wells at one location in the southern part of the Building 103 Dump site and immediately north of Building 7655. One of these wells is screened in the surficial aquifer at a depth of 16-21 ft. The USGS RFI data from these and other monitoring wells indicate that groundwater in the surficial aquifer and the deeper Canal Creek aquifer flows southwestward in the vicinity of the Building 103 Dump site. The potentially most significant contaminant migration pathways are sediment transport via surface water runoff, shallow groundwater, and deeper groundwater if DNAPL [dense nonaqueous phase liquid] materials were disposed of at the site. Sediment transport will not be significant if the area is not disturbed. The air pathway would not be significant unless any chemicals contained in tanks or ordnance are disturbed and released as a result of either volatilization or explosion.

Data from a first round of sampling analysis by the USGS showed a small amount $(10 \mu \mathrm{g} / \mathrm{L})$ of trans-1,2-dichloroethylene in the shallower well, and a larger amount $(164 \mu \mathrm{g} / \mathrm{L})$ of the same compound in the deeper well. The source of the trans-1,2-dichloroethylene may be the Building 103 Dump, but the source may also be upgradient of the dump. As part of RFI investigation work the USGS also did EM [electromagnetic] survey work in the area of the dump. That work indicated 
that there was a large amount of EM interference in the area, probably due to a combination of water lines, power lines, and buried metal items in the site.

It is recommended that interim remedial actions be taken to address the potential hazards associated with the buried tank in the Building 103 Dump which has been exposed as a result of erosion. The initial action should be removing and disposing of the tank contents without disturbing the tank itself. Interim remedial action should also include either marking of the site with warning signs and/or taking actions to ensure that heavy equipment is not taken onto the site and that digging in the area does not occur. [Note: When the area was surveyed by the ANL geophysical team in April and May of 1992, the tank contents had been removed and a permanent marker placed over the tank.] It is also recommended that ongoing RFI work by the USGS addressing groundwater contamination in the Canal Creek area be completed. The RFI work should address the Building 103 Dump to the extent necessary to determine if it is an ongoing source of groundwater contamination. If the site is not a continuing so'ice, long-term control of the site and monitoring of the groundwater may be preferable to cleanup of the site because of the possible hazards associated with cleanup.

As seen in Figure 2, the boundaries of the geophysical surveys were constrained by roads, a parking lot, and Building E5422. The survey area measured $135 \mathrm{ft}$ north-south $\times 250 \mathrm{ft}$ eastwest, considerably smaller than the dump area of $320 \times 280 \mathrm{ft}$ reported in the RCRA Facility Assessment Report. If the RCRA estimate is correct, it is probable that most of the north end of the original dump site has been included in the geophysical survey, but that the southern boundary was located $200 \mathrm{ft}$ further south of our survey boundary. The appearance of anomalies on the geophysical maps discussed in the following sections shows that the dump boundary does extend south beyond the limits of the geophysical survey and probably includes Building E5422 (i.e., the Building 655 referred to above).

\subsection{Site Reconnaissance}

The geophysical survey program for the Building 103 Dump was designed on the basis of results from a study completed between April 8 and April 19, 1991, for Building E5032 (McGinnis and Miller 1991), which is also located in the Canal Creek area (Figure 1). The initial evaluation was further enhanced by a visit to the site in November 1991. Access to the site is unrestricted.

In addition to surface conditions at the site, subsurface characteristics were considered in planning the geophysical surveying:

1. Surficial sediments consist of estuarine silts, sands, and clays that have intermediate resistivities and are nonmagnetic. The underlying soil properties 
are expected to vary both horizontally and vertically in the proximity of the site, depending on naturally occurring conditions anci on the presence of building excavations and operations.

2. Buildings and other attributes of the Edgewood section of Aberdeen, such as radio and radar transmissions, will contribute to interference of magnetic and electrical fields and will cause electromagnetic surveying (an easily applied, low-cost method that is frequently used to identify buried conductive objects) to be generally inapplicable (AEHA 1989).

3. Multiple sources, such as iron-rich magnetized objects, nonmagnetic objects. subsurface channels containing contaminants, and plumes of contaminants of variable resistivity, may be present in the subsurface.

Multiple working technologies were utilized in the program design to mitigate interference and to either directly detect or provide inferential data on subsurface characteristics.

\subsection{Geology and Physiographic Setting}

The site is contained in topographically low and flat terrain underlain by alluvial and estuarine sands, silts, and clays. Lithologies at the site were determined from the sample study of a borehole (site No. 23) drilled near the southern boundary of the dump. The descriptive log given in Table 1 was part of a hydrogeologic study of the Canal Creek area performed by the U.S. Geological Survey (Oliveros and Gernhardt 1989). Data from Table 1 were used to construct the lithologic log shown in Figure 3. Facies represented include soils and a clayey fill material to a depth of about $7 \mathrm{ft}$, followed by thin beds of varying stratigraphy to a depth of $14 \mathrm{ft}$. The greatest thickness $(15.3 \mathrm{ft}$ ) of a single unit was a clean sand ranging from a depth of 14 to $29.3 \mathrm{ft}$. This sand is recognized as part of the Canal Creek Aquifer (USGS 1992).

\subsection{Surveys}

The geophysical phase of the program at Building 103 Dump was carried out as planned during the period April 6 to May 8, 1992. Geophysical measurements conformed to the work plan (McGinnis et al. 1992), which called for magnetics, direct-current electrical resistivity (DCER), and ground-penetrating radar (GPR) surveys, as well as seismic refraction measurements. An addition to the plan was the use of a magnetic gradiometer/metal detector to ensure detection of anomalies between survey profiles and grid stations. Each technique had its own specific objectives:

- Gradiometer/metal detector sweep - to provide a rapid, $100 \%$ sweep of the site; 
TABLE 1 Lithologic Log of Borehole at Site No. 23

\begin{tabular}{lrr}
\hline \multicolumn{1}{c}{ Description } & $\begin{array}{c}\text { Depth } \\
\text { (ft) }\end{array}$ & $\begin{array}{c}\text { Thickness } \\
\text { (ft) }\end{array}$ \\
\hline $\begin{array}{l}\text { Soil, brown; with roots } \\
\text { Clayey fill material, orange-brown; with asphalt and wood }\end{array}$ & 0.4 & 0.4 \\
$\begin{array}{l}\text { Sand, clayey, orange to tan, [mL] } \\
\text { Clay, silty, white, friable, micaceous; with abundant small }\end{array}$ & 10.3 & 7.4 \\
red-purple concretions & 11.1 & 0.8 \\
$\begin{array}{l}\text { Sand, silty, multicolored, [mL-mU]; with small lenses of white } \\
\text { clay and small purple concretions }\end{array}$ & 14.0 & 2.9 \\
$\begin{array}{l}\text { Sand, tan, wet, clean, [mL]; with some orange staining and } \\
\text { lenses of clayey silt near bottom }\end{array}$ & 29.3 & 15.3 \\
$\begin{array}{l}\text { Sand, clayey, light gray to orange, [fL-fU]; with small, pink, } \\
\text { silty clay lenses and purple concretions }\end{array}$ & 34.0 & 4.7 \\
$\begin{array}{l}\text { Sand, pinkish-brown, poorly sorted [fU-mU]; with green and } \\
\text { ochre bands, and thin lenses of white silty clay }\end{array}$ & 39.0 & 5.0 \\
\hline
\end{tabular}

a Codes enclosed in brackets at selected horizons refer to color designations as specified in the Munsell Soil Color Charts (1975).

Source: Oliveros and Gernhardt (1989).

- Magnetometer measurements - to determine the location of such buried, ironrich objects as tanks, pipes, debris, etc.;

- Horizontal DCER survey - to establish the regional conductive nature of the subsurface and to identify contaminant plumes to depths of approximately $10 \mathrm{ft}$;

- Ground-penetrating radar survey - to determine the geometry of, and to find the approximate depth to, buried objects; and

- Shallow seismic refraction measurements - to gather information on seismic properties of the shallow sediments.

The following data were acquired during field operations: (1) nonpermanent ground markings of magnetic objects, (2) 391 magnetic observations, (3) 333 horizontal DCER observations, (4) 4,450 (linear) ft of GPR profile along 29 lines, and (5) two refraction soundings to a maximum source/receiver distance of $50 \mathrm{~m}$. Field operations required a total of two days for a four-person team. On-site personal computers (both notebook and desk top), interactive software, field equipment designed specifically for Aberdeen, and an all-terrain vehicle were used to expedite data acquisition and processing. 


\subsection{Survey Grid and Locations of Observations}

Prior to geophysical surveying, wooden stakes were placed at the site corners to mark the area to be surveyed so that its sides were approximately parallel to existing streets and buildings. The site borders were not perfectly aligned north-south and eastwest. Grid spacing was at $10-\mathrm{ft}$ intervals. The zero coordinate was at the southwest corner of the surveyed area. Positive numbers are measured north and east of the zero coordinate, whereas negative coordinates are measured south and west.
Site 23

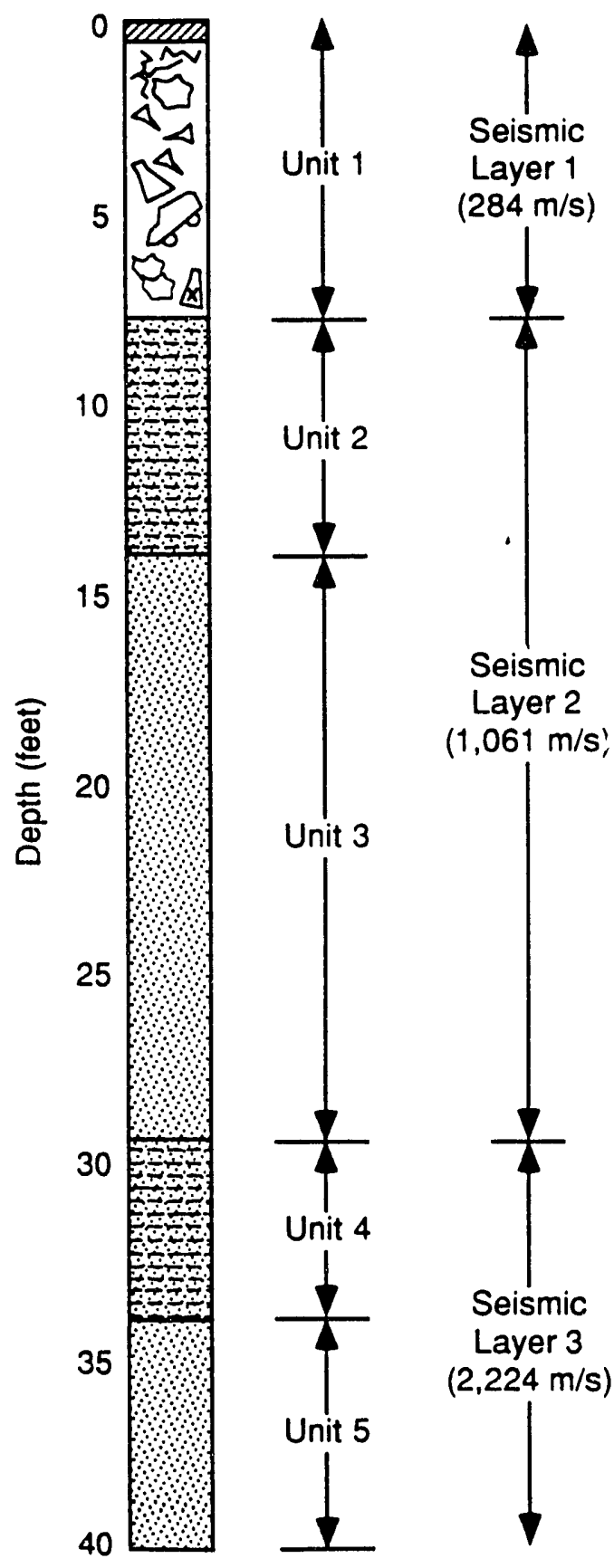

FIGURE 3 Lithologic Log of Borehole No. 23 near the South Margin of the Building 103 Dump and the Seismic Correlation 


\section{Instrumentation}

\subsection{Magnetic Gradiometer and Cable Locator}

The Schonstedt MAC-51B magnetic gradiometer and cable locator is a dual-mode instrument designed for detecting shallow buried iron and steel objects and tracing underground cables and pipes. The system consists of a transmitter and a dual-function receiver designed to detect anomalous magnetic gradients.

Maps or models are not constructed from observations made with the MAC-51B because it is not a calibrated system. The MAC-51B is an audio device used only for rapid detection of magnetic materials for further analysis with complementary instrumentation. Anomalies are identified by changes in sound amplitude and frequency and are marked on the ground surface prior to the initiation of other surveys. If anomalies detected with the MAC-51B cannot be verified with the magnetometer (see Section 2.2), the anomaly is assumed to be insignificant.

Application of the MAC-51B in its receiver mode was the first geophysical operation following establishment of survey limits. A qualitative description of the site with $100 \%$ ground coverage is achieved using the gradiometer, whereas the results obtained with other techniques, although more quantitative, are spatially limited to single-point, survey-grid observations or to continuous readings along spaced profiles.

\subsection{Magnetometer/Gradiometer}

Magnetics is the best technique for identifying such buried magnetized objects as tanks, drums, and small iron-rich debris. The EDA OMNI IV magnetometer/gradiometer is a total-field, proton-precession, microprocessor-based instrument that can measure magnetic gradients and, consequently, identify buried magnetic objects. Internal software permits down-loading directly into an on-site computer.

Two sets of magnetic observations were made at 10 -ft spacings along profiles; for one data set, the sensor head was located on the ground surface, and for the other, it was located $8 \mathrm{ft}$ above the surface. The two grid sets that resulted from this survey allowed differentiation between magnetic anomalies caused by shallow-buried objects and those caused by more deeply buried objects. Both sets of magnetic observations were contoured using SURFER V. 4.0 software by Golden, Inc. (1991), to identify potential sources of contaminants and to distinguish them from background. The SURFER software was incorporated into the field acquisition procedure, so that daily map outputs were available for observation and interpretation. 
The earth's magnetic field is reasonably well-known at a given time and place, although changes in the field occur daily and during magnetic storms. To adjust for field changes, the instrument has internal calibration to correct observations made at cross lines and base stations. Repeat readings were used to correct data for diurnal field fluctuations.

\subsection{Direct-Current Electrical Resistivity Meter}

Data on the electrical properties of soils at APG may permit detection of abnormally conductive or nonconductive liquid or solid contaminants. Most of the electrical properties of sedimentary materials are a product of the chemistry of interstitial fluids. Consequently, resistivity data can be diagnostic and complement magnetic and radar measurements. Direct-current electrical resistivity measurements have been incorporated into the APG study to take the place of the conductivity measurements using electromagnetic methods that are typically made for investigations of this type. Electromagnetic methods could not be used because of the previously reported interference problems (AEHA 1989).

Resistivity equipment used on the Aberdeen project consisted of an $A B E M$ Terrameter and Booster, model SAS 300C, that utilized a variety of electrode configurations. A modified, eightelectrode Wenner array with a 2-m electrode spacing was the configuration selected for horizontal profiling to provide maximum information between the surface and a depth of $10 \mathrm{ft}$. The array was towed behind an all-terrain vehicle. Profiles were coincident with GPR and magnetic lines, and data were recorded at $10-\mathrm{ft}$ intervals along the lines. Consistency of repeat observations over a test profile and over known electrical anomalies provided assurance of relative data quality. Data were contoured using SURFER software as described in the magnetics section.

Electrical depth-sounding curves using a Schlumberger electrode array were obtained from resistivity stations located $400 \mathrm{ft}$ east and west of the dump to add a three-dimensional view to the horizontal mapping. The sounding curve was interpreted using a Schlumberger software code named RESIX PLUS, written by Interpex (1988). Resistivities of undisturbed soils were comparable with those observed at Building E5032, which averaged $60 \Omega-\mathrm{m} .{ }^{*}$ (See Appendix A for further information.)

\subsection{Ground-Penetrating Radar System}

Ground-penetrating radar surveying was accomplished using a Geophysical Survey Systems, Inc. (GSSI), model SIR-3 radar connected to a transceiver with a 90-m cable. Data were recorded on a digital audio tape to permit playback and computer processing. The control unit/graphic recorder was located in the transport vehicle. An IBM-compatible processing

\footnotetext{
* Resistivity data acquisition and processing were done using the metric system of measurement. To convert from meters to feet, multiply values given in meters by 3.28 .
} 
computer was located in a field office, so that the radar operator could down-load, check data-tape quality, and do preliminary processing after a day's run. Radan I computer software written by GSSI was used for processing the GPR data.

Continuous GPR profiles spaced $20 \mathrm{ft}$ apart were run over the site, coincident with magnetics and resistivity lines. Additional GPR profiles were collected in the northwest portion of the site to get a more detailed survey around the known buried tank. The locations of all the GPR profiles for the Building 103 Dump are given in Appendix B. During initial surveys, several lines weie run across the same profile using different transceivers and instrument settings to determine optimum effectiveness. Antennas were pulled by hand at approximately $3 \mathrm{ft} / \mathrm{sec}$.

Wave-velocity characteristics of materials to be found at the Aberdeen/Edgewood area were derived from known positions of buried objects. Internal calibration was run at least twice each day to ensure that the graphic record of the range setting was consistent. Studies conducted during the 1991 field season suggest wave velocities of 6-7 ns/ft for near-surface sediment at Aberdeen. However, characteristics vary with the heterogeneity of the subsurface. Typical wave velocities for different materials are shown in Table 2.

Ground-penetrating radar is probably the best method available to determine depth and geometry of objects buried near the surface. The weakness of the method is its limited depth of exploration due to wave-propagating constraints imposed by the electrical properties of soils. The maximum depth of penetration with GPR at the Building 103 Dump was approximately $8 \mathrm{ft}$ below the ground surface.

TABLE 2 Approximate Two-Way Travel Times for Various Materials

\begin{tabular}{|c|c|c|c|}
\hline Material & $\begin{array}{l}\text { Two-Way } \\
\text { Travel Time } \\
\left(10^{-9} \mathrm{~s} / \mathrm{ft}\right)\end{array}$ & Material & $\begin{array}{l}\text { Two-Way } \\
\text { Travel Time } \\
\left(10^{-9} \mathrm{~s} / \mathrm{ft}\right)\end{array}$ \\
\hline Air & 2 & Marshy forested land & 7 \\
\hline Fresh water & 18 & Rich agricultural land & 8 \\
\hline Sea water & 18 & Fresh-water ice & 4 \\
\hline Sand (dry) & 4.5 & Granite (dry) & 4.5 \\
\hline Sand (saturated) & 11 & Limestone (dry) & 5 \\
\hline Silt (saturated) & 6 & Concrete & 5 \\
\hline Clay (saturated) & 6 & Asphalt & $4-5$ \\
\hline Dry, sandy, coastal land & 6 & & \\
\hline
\end{tabular}

Source: Geophysical Survey Systems, Inc. (1987). 


\subsection{Seismograph}

Two seismic refraction soundings were made with an EG\&G Geometrics, Model 2401, 24-channel seismograph and $20-\mathrm{Hz}$ geophones with a sledgehammer sound source. Geophone spreads were 1 and $2 \mathrm{~m}$, with maximum spread length of $50 \mathrm{~m}$. Data were recorded on 3.5-in. disks and processed with software including the Interpex code GREMIX, which uses the GRM method and RIMROCK code SIPT2. Seismic data were acquired as a test to see if seismic boundaries were coincident with the lithologic boundaries defined by the drilling log as shown in Figure 3. 


\section{Geophysical Measurements and Surveys}

\subsection{Magnetometer Measurements}

Details of shallow-burial characteristics of a landfill are best seen with the magnetic sensing head resting on the ground. More deeply buried objects and the configuration of the regional magnetic field are best viewed with the sensing head elevated further above the magnetic sources. In order to optimize the resolution of both shallow and deep sources and to gain some understanding of trends in burial depths, ANL staff surveyed the landfill area twice: one survey where the sensor was at the ground surface, with the results shown in Figure 4, and a second survey with the sensor $8 \mathrm{ft}$ above the ground, with the results presented in Figure 5.

Total magnetic field intensities were read at 782 positions located at 10-foot intervals; 391 observations were recorded with the sensing head resting on the ground and 391 with the sensing head $8 \mathrm{ft}$ above ground. Data were contoured at a contour interval of 500 gammas in Figure 4 and 200 gammas in Figure 5. Magnetic field intensity at this site ranges from a minimum of 47,828 gammas to a maximum of 79,485 gammas with the sensor on the ground and from 51,828 to 57,525 gammas with the sensor elevated.

As expected, the general configuration of the two maps is similar; however, magnetic gradients and field intensities display fundamental differences because of the inverse square law describing the magnetic force between poles. The difference is best illustrated in the results over a partially buried pipe in the southwest corner of the dump. With the sensing head on the ground, an intense magnetic field is centered directly over the pipe, about $20 \mathrm{ft}$ west of its east end. With the sensing head elevated, the anomaly is more diffuse and is centered off the map to the west and slightly north of the pipe. Other results include some very shallow sources suggested by intense, high-gradient anomalies in the northwest quadrant of Figure 4. The tank containing organic chemicals that was discussed in the site history is located at the south edge of a high intensity anomaly in Figure 4 and next to a high magnetic gradient oriented southwest-northeast in Figure 5. A marker located at map coordinates $85 \mathrm{~N}, 46 \mathrm{E}$ identifies the tank's location (see Figure 2).

Anomaly gradients in Figure 5 are generally lower than those in Figure 4. Because of the decrease in gradients, it is probable that burial is deeper to the southeast, although the volume of ferromagnetic material may be greater. Buried magnetic debris is contained in a dendritic pattern similar to that of a stream tributary. This characteristic is particularly evident in Figure 5. A magnetic anomaly having an amplitude of 2,000-3,000 gammas in Figure 5 forms the major trunk line, trending northwest-southeast, roughly imaging current topography and drainage. A filled, former drainage system would also explain the deepening of sources to the southeast. It is probable that the area surveyed covers only the northern third or half of the former dump and that magnetic anomalies in the main tributary continue on to the south. 

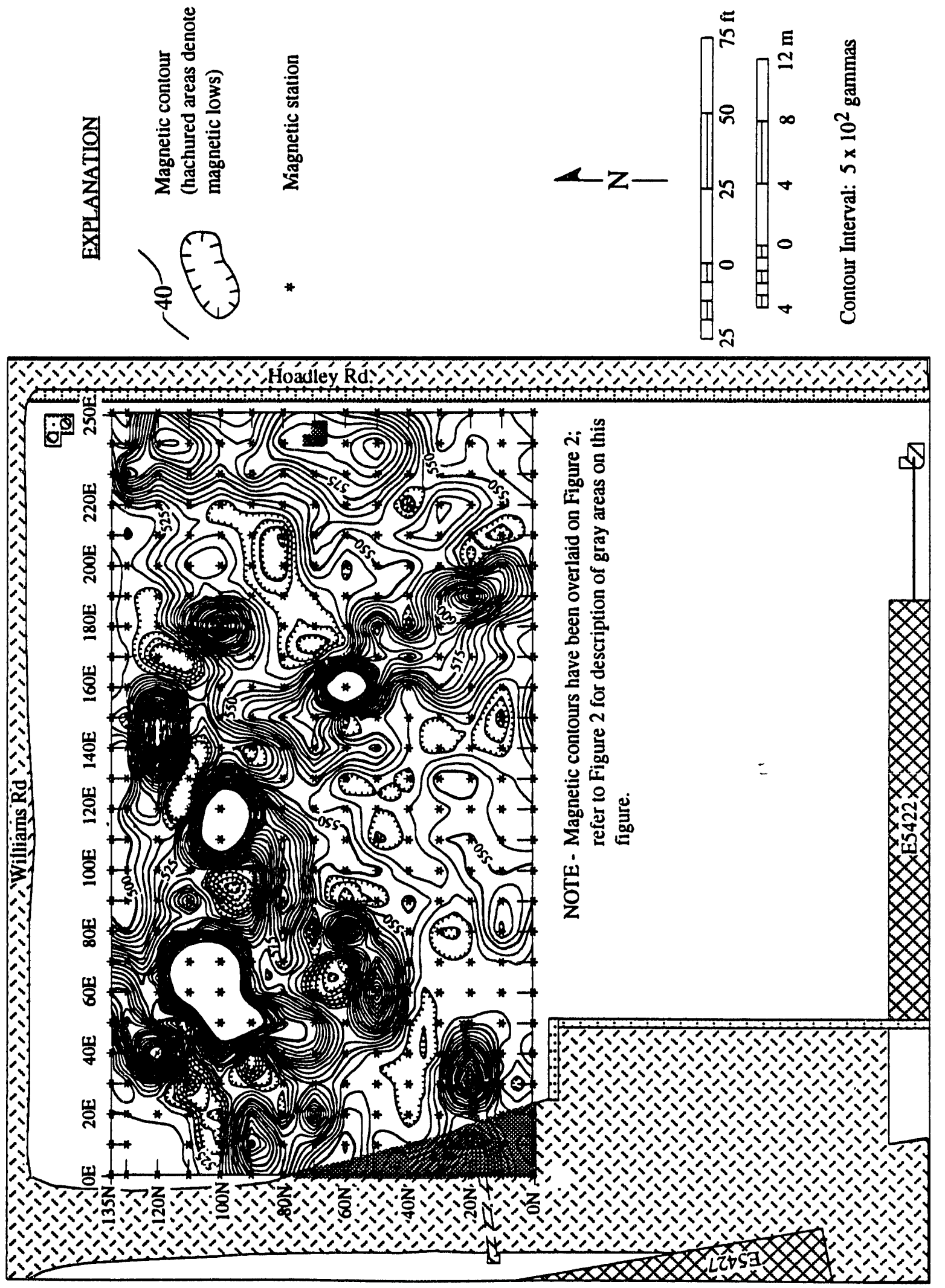

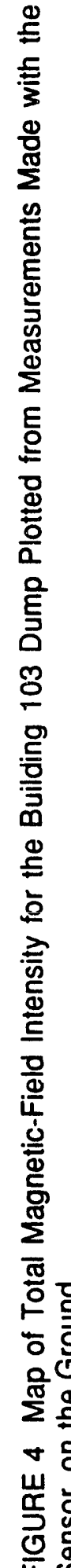




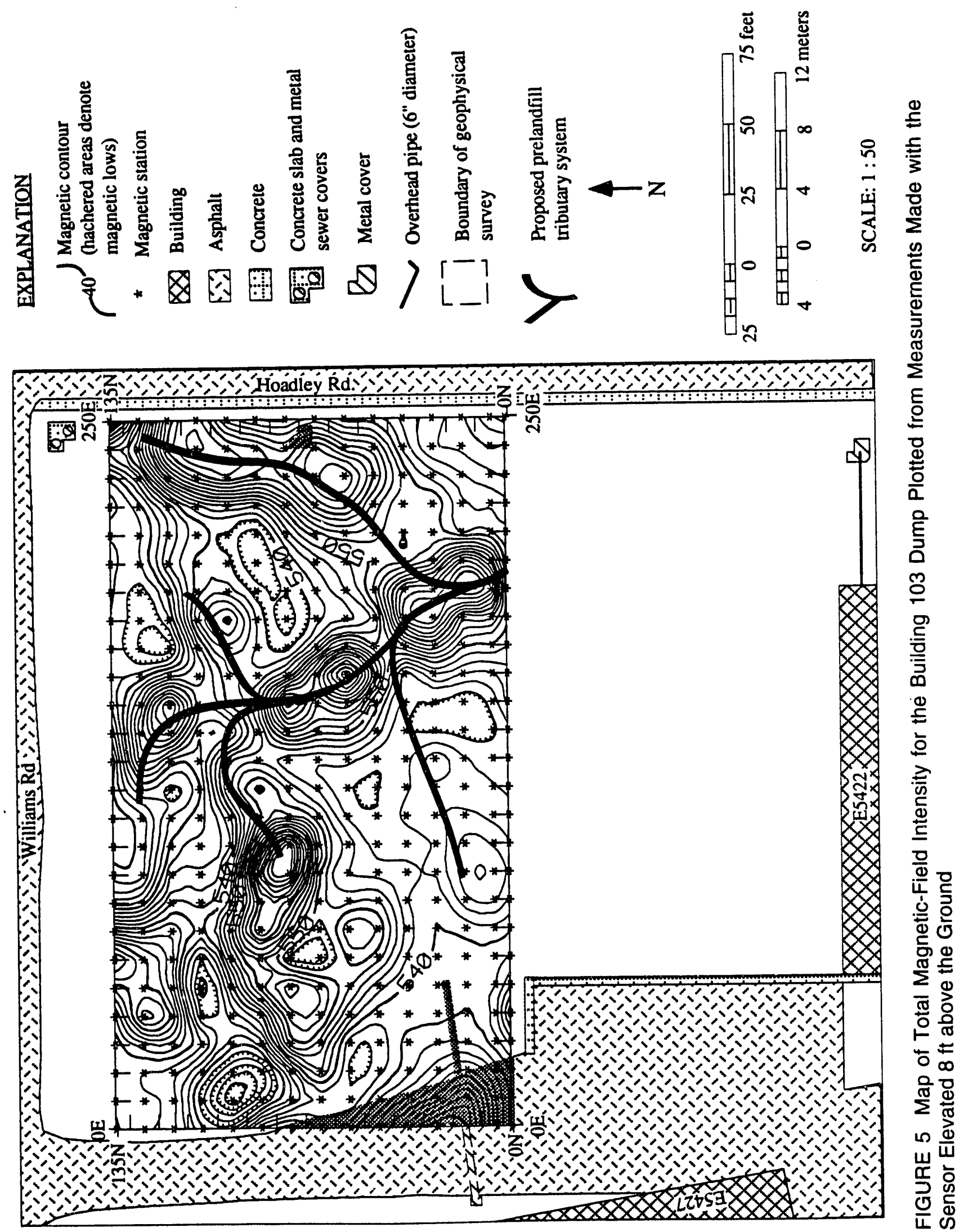




\subsection{Direct-Current Electrical Resistivity Measurements}

Horizontal DCER survey results are illustrated in Figure 6. The electrode spacing was $2 \mathrm{~m}$, a configuration that provides an average resistivity for materials lying between the surface and a depth of about $10 \mathrm{ft}$. Apparent resistivity values range from $4 \Omega-\mathrm{m}$ in the southeast quadrant of the landfill to $850 \Omega-\mathrm{m}$ in the northwest quadrant. The major feature on the resistivity map is a conductive lineament trending northwest-southeast and centered at $50 \mathrm{~N}, 155 \mathrm{E}$. The north end of the lineament branches out to the west and northeast. A far less prominent anomaly is also a conductive feature in the southwest corner of the landfill and is caused by a drainpipe partially exposed at the surface. Lines connecting resistivity minima also have the appearance of a dendritic drainage pattern.

Two electrical depth-sounding measurements, assumed to represent background, were made in relatively undisturbed areas $400 \mathrm{ft}$ east (at Building E5282) and $400 \mathrm{ft}$ west (at Building E5481) of the dump. Interpretations of the curves plotted from these measurements (see Appendix A) indicate resistivities on the order of $300 \Omega$-m in the dryer soils near the surface and $100 \Omega-\mathrm{m}$ at a depth of $4-5 \mathrm{~m}$. It is probable that the deeper resistivities are representative of saturated sands, silts, and clays of the surficial aquifer.

\subsection{Ground-Penetrating Radar Measurements}

Ground-penetrating radar measurements were made over $4,450 \mathrm{ft}$ of traverse along 29 individual profiles. The lines are numbered in sequence and are listed in Appendix B, along with the beginning and ending positions relative to the grid survey. Prior to running the production lines for the survey, replicate runs were made to determine which of the three transceivers - the $80-, 300-$, or $500-\mathrm{MHz}$ antenna - was best suited to study the terrain surrounding the site. The transceiver providing the best penetration and resolution of buried objects was the $300-\mathrm{MHz}$ unit. Different range settings were also tested over the same transect to determine the optimum resolution and depth of penetration. A range setting of $90 \mathrm{~ns}$ was used for the entire survey at a scan rate of 16 scans per second.

GPR profiles over fill material are shown in Figures 7a and $7 \mathrm{~b}$. The vertical scale is shown on the right side of the profiles, whereas the horizontal scale is defined by broken, vertical marker lines at 10 -ft intervals. Perimeter profiles were designed to detect buried objects extending radially from the site.

Without verification by another technique or by passing the antenna over a known buried object, characteristics of radar anomalies may only be inferred. However, where anomalies are also seen with the magnetometer or electrical resistivity meter, some interpretation of the radar anomaly is possible. 

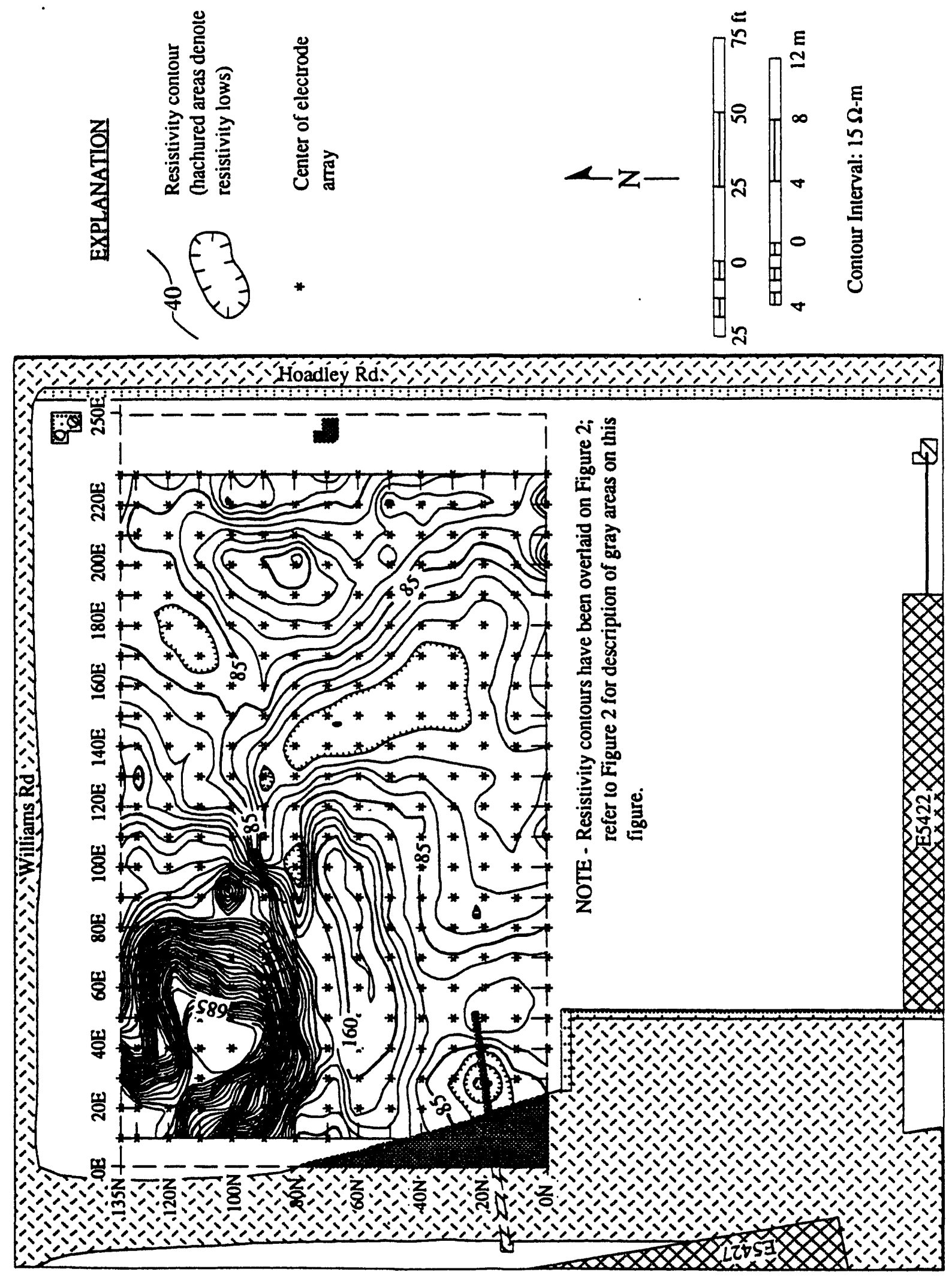

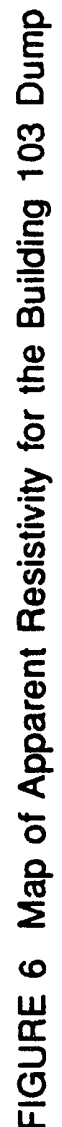


$\varpi$

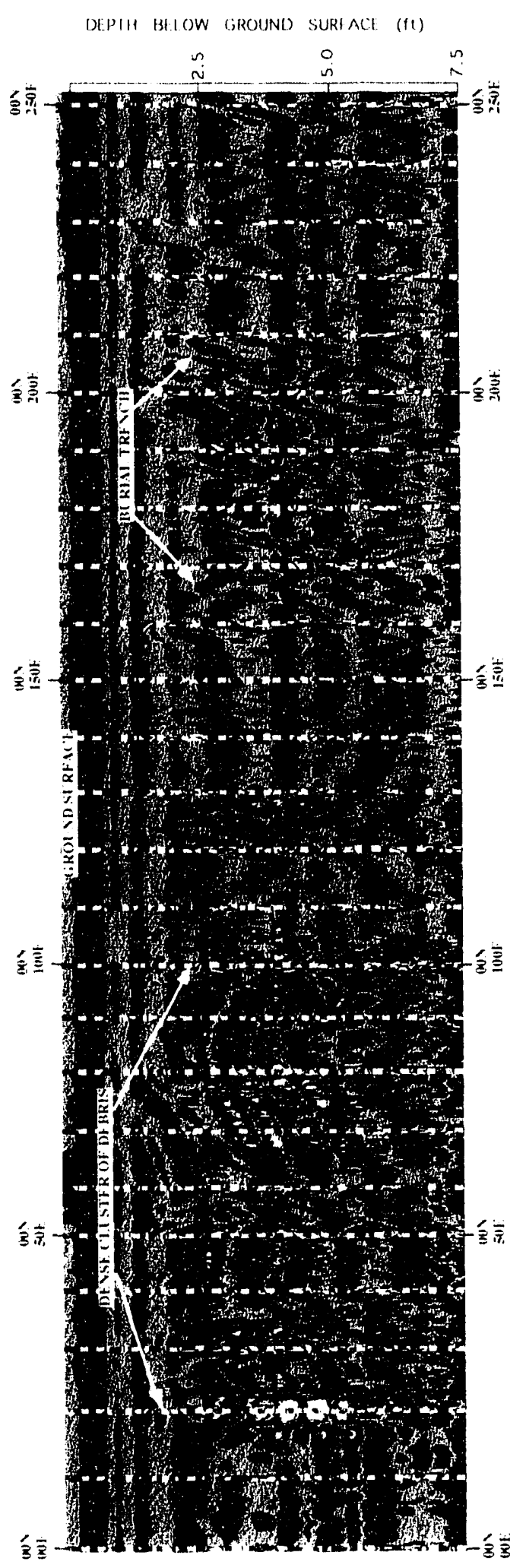

동

을

DHPIH BEL.OW GROUND SURTACE (ft)

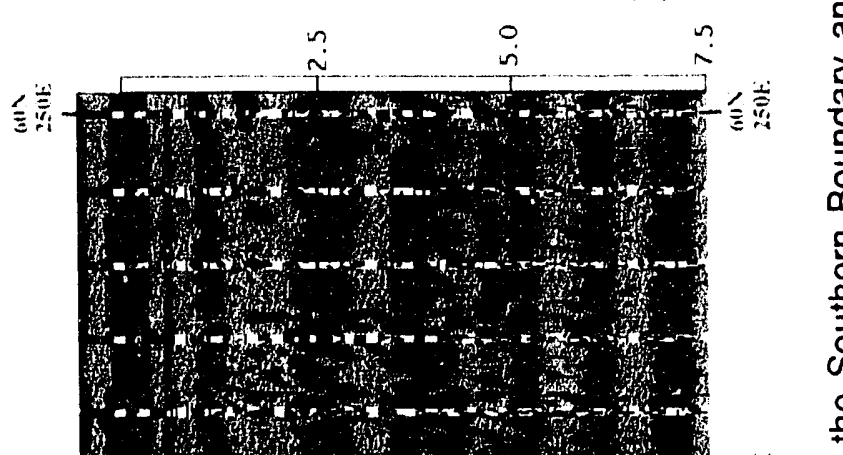

兵

음

త్ర

을

움

号

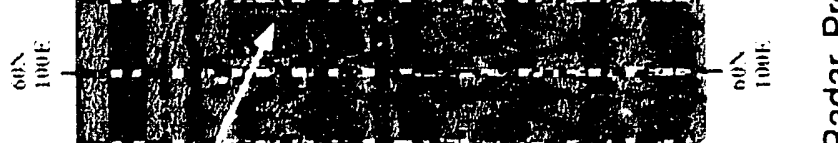

营

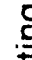

Фั

造选

을

인?

जि

똥

щั.

㐫

$\stackrel{0}{2}$

$\wedge \bar{\pi}$

㟧

讨

인. 
Good penetration down to the top of buried debris was observed over most of the site, with resolution to about $8 \mathrm{ft}$ below the ground surface. The major findings of the GPR survey at the Building 103 Dump are the following:

1. West-east GPR profiles collected in the southern half of the site clearly show a trench that trends from southeast to northwest in the eastern half of the survey area. The width of this trench varies, but the average is approximately $40 \mathrm{ft}$. The trench appears to contain large amounts of debris buried within $2-2.5 \mathrm{ft}$ of the surface. The exact contents of the trench cannot $t$ e determined, but on the basis of the high reflectivity of some of the anomalies, it can be concluded that the trench contains some metallic debris. Two GPR profiles across this trench can be seen in Figures 7a and b. Line No. 1, shown in Figure 7a, was collected along $00 \mathrm{~N}$ and shows the trench between grid coordinates $00 \mathrm{~N}, 165 \mathrm{E}$ and $00 \mathrm{~N}, 205 \mathrm{E}$. This trench is also seen $60 \mathrm{ft}$ north in line No. 4, shown in Figure $7 \mathrm{~b}$, where the trench is located between grid coordinates $60 \mathrm{~N}, 140 \mathrm{E}$ and $60 \mathrm{~N}, 170 \mathrm{E}$. These profiles also reveal an unidentified, discontinuous, flat-lying reflector at a depth of 3.0-3.5 ft. The area east of this trench appears to be relatively undisturbed and does not reveal any significant GPR anomalies.

2. Lines No. 1 and No. 4 also reveal scattered buried debris. The western edge of this debris $(00 \mathrm{~N}, 20 \mathrm{E})$ corresponds with the edge of the asphalt on the west side, and the debris appears to extend approximately $80 \mathrm{ft}$ to the east $(00 \mathrm{~N}, 100 \mathrm{E})$. The debris, buried at a depth of $1.5-2.0 \mathrm{ft}$ below the ground surface, appears to be a dense cluster of small objects, some of which may be metallic.

3. The majority of the GPR profiles made at the dump were collected in the northwest quadrant of the site, to better characterize the buried tank. However, the northwest quadrant contains so much buried debris that it was impossible to distinguish the tank from the surrounding debris.

\subsection{Seismic Refraction Measurements}

Two seismic refraction measurements, with spreads oriented east-west, were made over the site. The sound source was a sledgehammer blow, and receivers included 24 geophones located at 2-m intervals along the spread for station APG1 and at 1-m intervals for station APG2. Station APG l, with the western shot point located at $65 \mathrm{~N}, 80 \mathrm{E}$, was located over the primary magnetic and resistivity anomaly in the landfill. Time-distance data for staticin APG1 are plotted in Figure 8. A three-layer interpretation of APG1 is shown in Figure 9. Mean compressional wave velocities of the reversed spread at APG1, in descending order, are 284, 1,061, and 2,224 m/s. Station APG2 was located on the west flank of the resistivity and magnetic anomalies. It is also interpreted as a three-layer model, with mean velocities of 247,920 , and $1,650 \mathrm{~m} / \mathrm{s}$. Both time-distance curves 


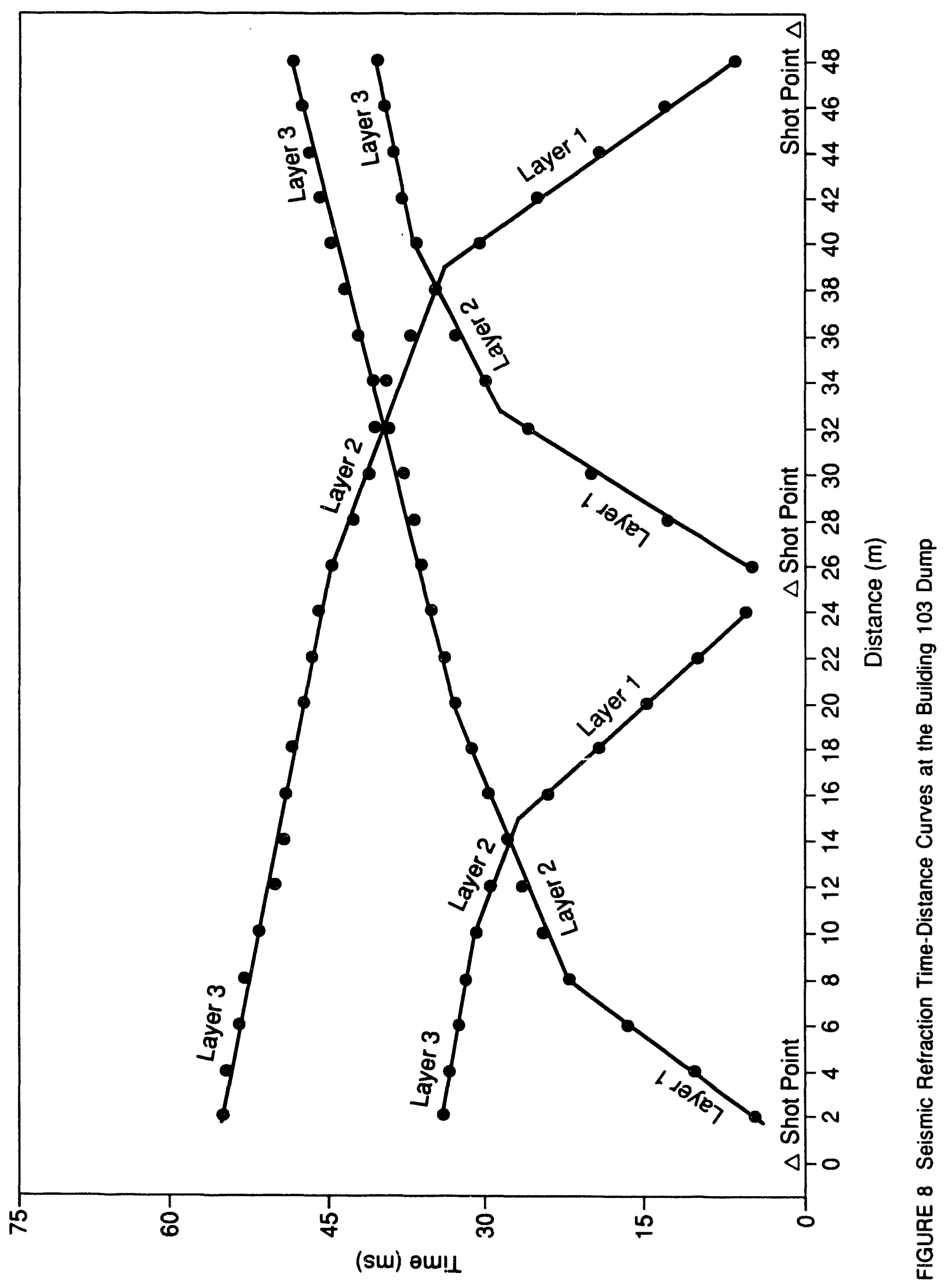




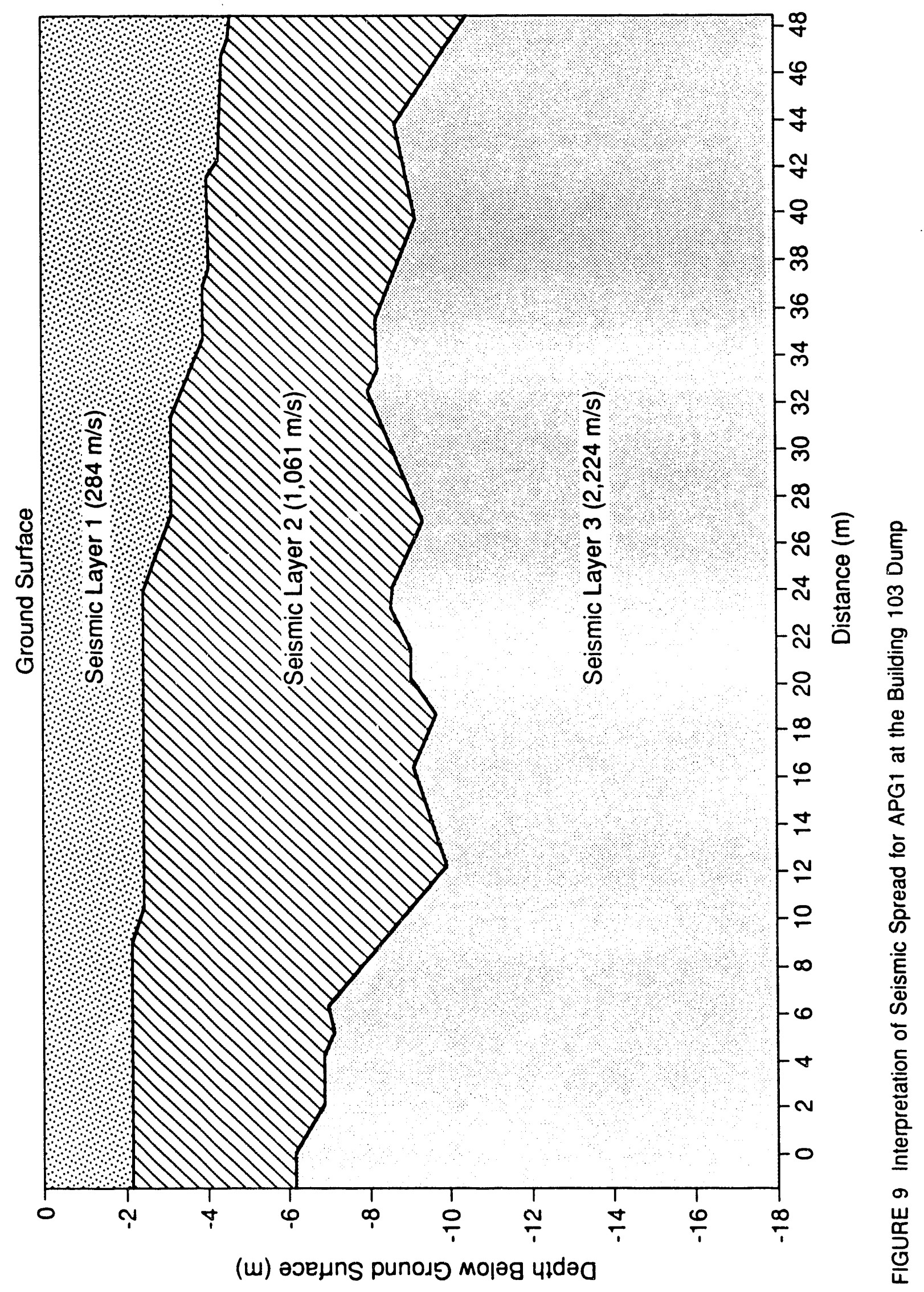


display zones of continuously increasing velocities between layers 1 and 3 . The spread length at APG2 was too short to obtain a valid velocity for layer 3; therefore, the velocity of $1,650 \mathrm{~m} / \mathrm{s}$ is only an intermediate value.

Layer 1 at APG1 (Figure 9) is interpreted to represent unsaturated landfill material. The base of layer 1, dipping to the east from a depth of $2-4 \mathrm{~m}$, is believed to be the former land surface. Layer 2 , having a mean velocity of $1,061 \mathrm{~m} / \mathrm{s}$, is transitional material consisting of surficial soils, silty sands, and clean sands of the surficial aquifer. Seismic layer 2 corresponds with Units 2 and 3 on the geologic $\log$ of Figure 3 . Units 2 and 3 are probably of Pleistocene/Holocene age and represent fill material deposited in a Pleistocene channel during latePleistocene sea-level rise. The base of layer 2 dips to the east from 6 to approximately $10 \mathrm{~m}$. Seismic layer 3 , having a mean velocity of $2,224 \mathrm{~m} / \mathrm{s}$, corresponds with Units 4 and 5 in Figure 3. Unit 4 is a clayey sand, whereas Unit 5 consists of clean saturated sands. The top of Unit 4, corresponding to the depth of the beginning of the $2,224 \mathrm{~m} / \mathrm{s}$ seismic layer, may represent the top of Cretaceous coastal plain sediments.

The rationale for the above interpretations is as follows. The water table at the Building 103 Dump is at a depth of about $3.6 \mathrm{~m}$ (Oliveros and Gernhardt 1989). Therefore, the surficial velocity of a few hundred meters per second represents dry fill. The second layer is transitional from dry to saturated. Therefore, a mean velocity of approximately $1,000 \mathrm{~m} / \mathrm{s}$, which is $500 \mathrm{~m} / \mathrm{s}$ less than saturated velocity for soft sediments, is an appropriate value for this layer. The velocity of $2,224 \mathrm{~m} / \mathrm{s}$ is too high for saturated, unconsolidated, Pleistocene valley fill deposits; therefore, seismic layer 3 is assumed to be Cretaceous in age and to correspond with Unit 4, a clayey sand on the geologic log (Figure 3). Unit 4 may also represent the hydrogeologic unit known locally as the Upper Confining Layer. 


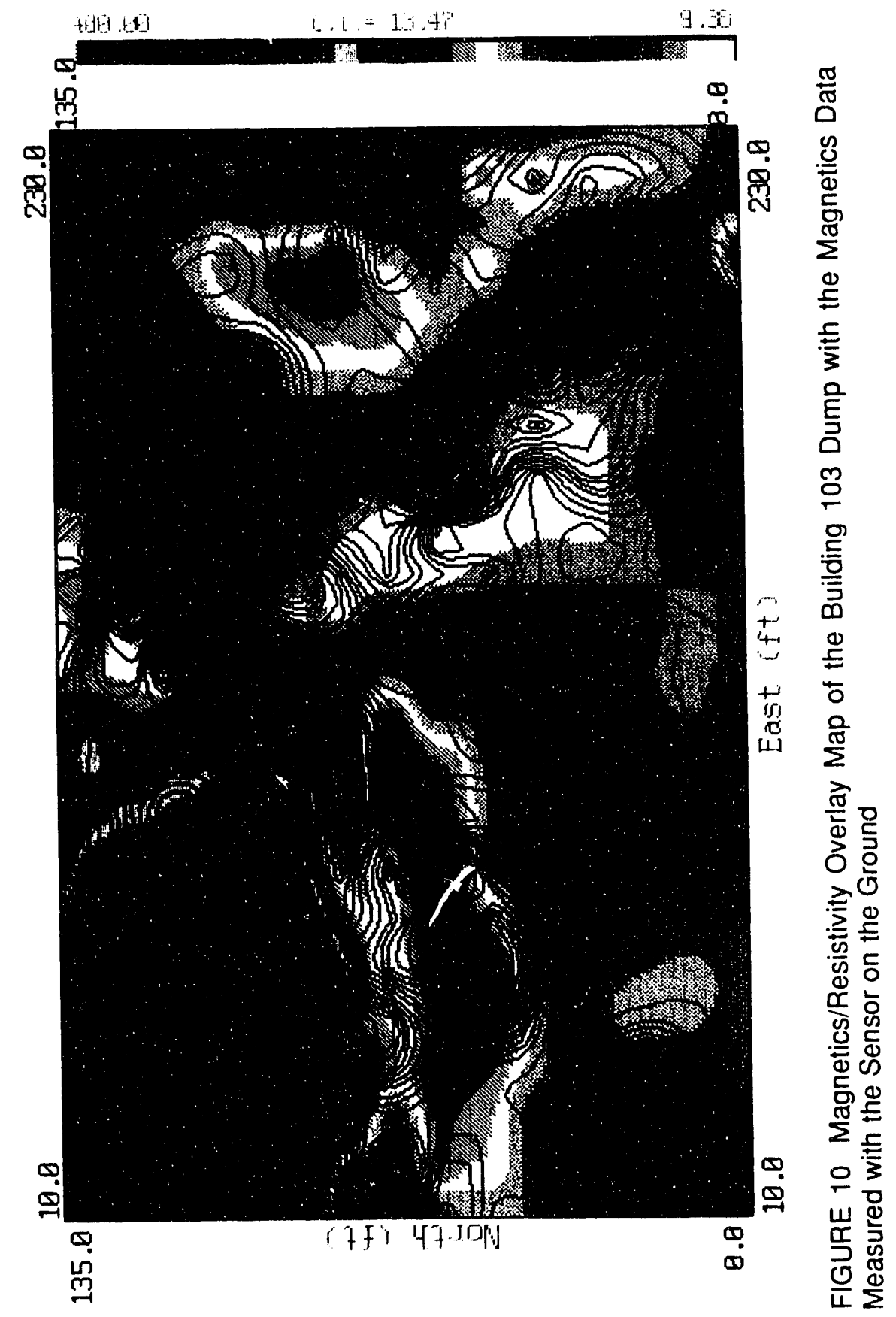




\section{Discussion}

Contour maps of the magnetics data overlaid on the resistivity measurements have been prepared in color. In Figure 10, the magnetics data were measured with the magnetic sensor on the ground, and in Figure 11, the sensor was elevated $8 \mathrm{ft}$ above ground. Because of the high magnetic gradients, the contour interval in Figure 10 is 500 gammas, whereas a 200-gamma interval was satisfactory for Figure 11. A general decrease in magnetic gradients to the southeast on both maps indicates an increase in burial depth of ferromagnetic fill in the southeast section of the site.

In general, conductive zones show a strong correlation with magnetic positives, although the most conductive feature, trending southeast from the center of the map, bends to the southwest at $30 \mathrm{~N}, 150 \mathrm{E}$ without an immediately apparent magnetic equivalent. Magnetic and electrical lineaments are arranged in a pattern suggestive of a stream tributary system (Figure 5). It is probable that the original Building 103 Dump was located in a tributary to the East Branch of Canal Creek. The comment in the AEHA report (see Section 1.1) that the dump was originally a sand pit may indicate that the sand was an outcrop of the surficial aquifer. Headward erosion and development of the Canal Creek tributary system during Pleistocene sea-level lowering provided a convenient surface depression for the dumping of waste. Therefore, if contaminants were dumped into the landfill, they would have direct and immediate access into the surficial aquifer and Canal Creek.

The GPR data also show a strong correlation with the magnetic data. The magnetic anomaly trending southeast from the center of the survey area, which is shown in Figures 4, 5, 10 , and 11, is clearly identified in several GPR profiles. This linear feature is most likely a trench filled with an assortment of debris, some of which is iron-bearing metal. The large magnetic anomaly that encompasses the northwest quadrant is seen in GPR profiles as large amounts of debris buried near the ground surface. Due to all the debris near the buried tank, the tank was not distinguishable in the GPR profiles.

Interpretation of the seismic refraction profile (Figure 9) shot over the major magnetic and resistivity anomalies in the southeast quadrant indicates that refracting layers dip to the east. Layer 1 in Figure 9 consists of landfill debris and fill material. Layer 2 is interpreted to be prelandfill sediments upon which fill was dumped. This layer, consisting of clayey sands and clays and having a seismic velocity of $1,061 \mathrm{~m} / \mathrm{s}$, slopes to the east from 2 to $4 \mathrm{~m}$ below the present land surface and is believed to be the upper part of the surficial aquifer. Seismic layer 3 , having a velocity of $2,224 \mathrm{~m} / \mathrm{s}$ and also dipping to the east, is interpreted to be representative of the top of the Cretaceous, which may also represent the top of the Upper Confining Layer. The top of this refractor correlates with the contact at the base of a $15.3 \mathrm{ft}$-thick sand unit and the top of a clayey sand at a depth of $29.3 \mathrm{ft}$, as noted on the log of borehole No. 23 in Table 1 and Figure 3. 


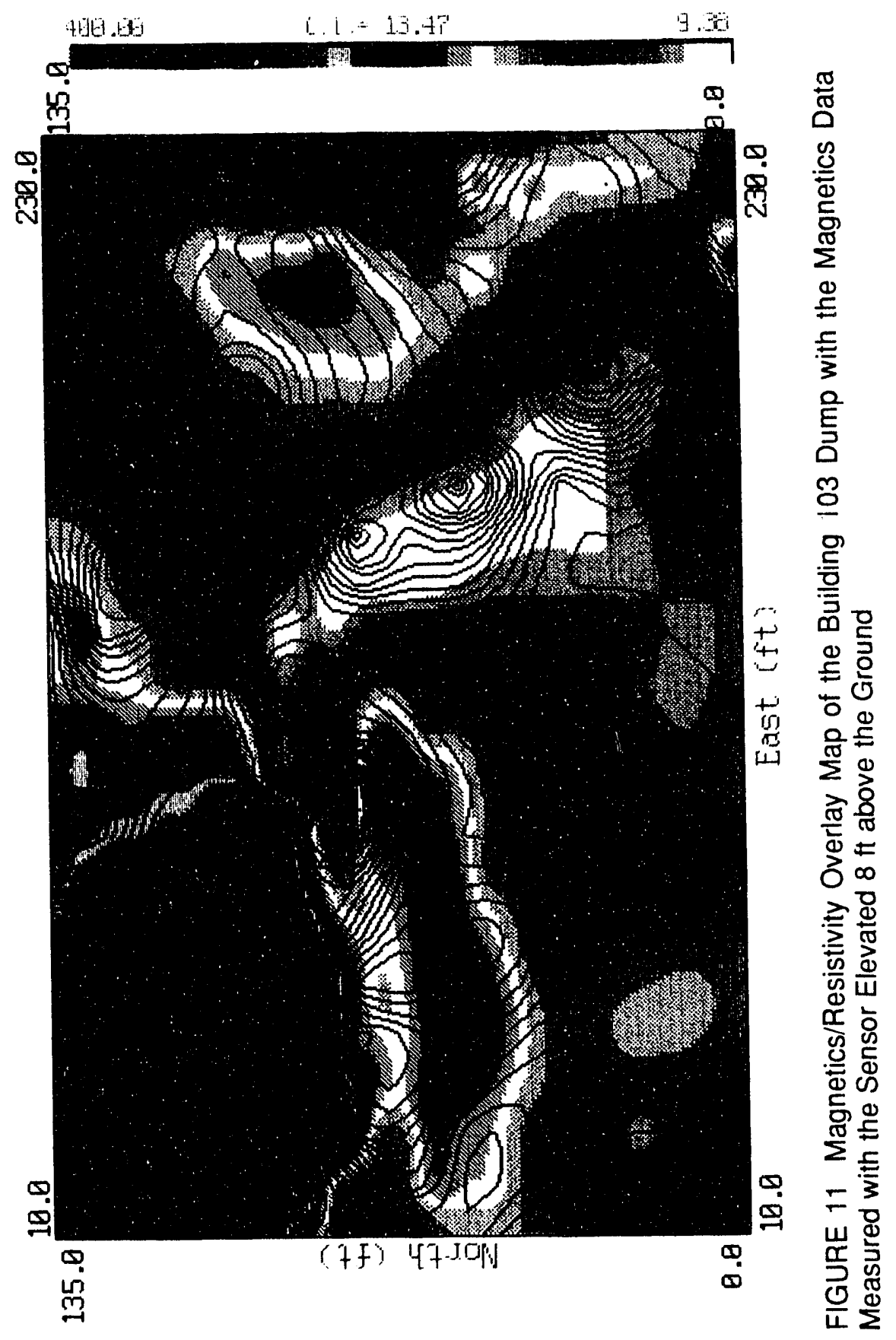




\section{Conclusions}

Specific conclusions drawn from the site surveys at the Building 103 Dump are as follows:

1. Prominent magnetic, resistivity, and GPR anomalies are present over the former landfill.

2. Anomalies are arrayed in linear, dendritic patterns suggestive of a stream tributary.

3. A historical summary of the site in the AEHA report (1989) describes the dump as a sand pit, which suggests that headward erosion of Canal Creek tributaries cut into the surficial aquifer, causing the aquifer to outcrop prior to conversion of the tributary to a landfill.

4. Contaminants dumped into the landfill would have direct access to the surficial aquifer and, thus, to Canal Creek.

5. Seismic refraction profiling over the landfill indicates that the former land surface dips to the east at a mean depth of $3 \mathrm{~m}$ below the profile and that the base of the surficial aquifer can be mapped with seismic refraction measurements.

6. Only about one-third of the former landfill was geophysically surveyed. Most of the landfill lies south of the surveyed area.

7. Ongoing RFI work by the U.S. Geological Survey addressing groundwater contamination should be completed in order to determine if the Building 103 Dump is a source of groundwater contamination. 


\section{References}

AEHA: see U.S. Army Environmental Hygiene Agency.

EAI Corporation, 1989, Historical Records Search and Site Survey of Edgewood Area Buildings, Final Report, prepared for U.S. Army Chemical Research, Development, and Engineering Center, Aberdeen Proving Ground, Md., under contract No. DAA15-87-D0021.

Geophysical Survey Systems, Inc., 1987, Operations Manual for Subsurface Interface Radar (SIR System-3).

Golden Software, Inc., 1991, Surfer Version 4, Golden, Colo.

Interpex Limited, 1988, RESIX PLUS User's Manual, Golden, Colo.

McGinnis, L.D., and S.F. Miller, 1991, Interim Progress Report-Geophysics: Building E5032 Decommissioning, Aberdeen Proving Ground, report ANL/ESD/TM-20, Argonne National Laboratory, Argonne, Ill.

McGinnis, L.D., S.F. Miller, M.G. McGinnis, and M.D. Thompson, 1992, unpublished information, Argonne National Laboratory, Argonne, Ill.

Munsell Soil Color Charts, 1975, Macbeth, a division of Kollmorgen Corp., Baltimore, Md.

Oliveros, J.P., and P. Gernhardt, 1989, Hydrogeologic Data for the Canal Creek Area, Aberdeen Proving Ground, Maryland, April 1986-March 1988, U.S. Geological Survey Open-File Report 89-387.

USAEA: see U.S. Army Edgewood Arsenal.

U.S. Army Edgewood Arsenal, 1946, Diary, Edgewood Arsenal, 1937-1946, prepared by Commanding Officers, Edgewood Arsenal.

U.S. Army Environmental Hygiene Agency, 1989, RCRA Facility Assessment Report, Edgewood Area, Aberdeen Proving Ground, Maryland. 
U.S. Geological Survey, 1992, Contamination of Groundwater, Surface Water, and Soil and Evaluation of Selected Pumpage Scenarios in the Canal Creek Area of Aberdeen Proving Ground, Maryland, draft open-file report.

USGS: see U.S. Geological Survey 
Appendix A:

Electrical Depth-Sounding Curves 


\section{Appendix A:}

\section{Electrical Depth-Sounding Curves}

Four Schlumberger electrical depth soundings near buildings in the Edgewood area provide a depth dimension to resistivities of soils, sediment, and anomalous unidentified materials. Soundings were made near Buildings E5282, E5440, E5481, and E5974. The sounding made at Building E5282 was the nearest sounding to the Building 103 Dump. Locations of centers of stations and orientations of electrode arrays are listed in Table A.1, and the curves are shown at the end of Appendix A as Figures A.1-A.4.

Inversion of these curves using the Interpex code, RESIX PLUS (Interpex Limited 1988), indicates that resistivity of dry soils ranges from 200 to $300 \Omega-\mathrm{m} ;{ }^{*}$ saturated sediments, about $100 \Omega$-m; saturated, organic-rich sediments, about $200 \Omega-\mathrm{m}$; and anomalous materials range from less than 10 to $10,000 \Omega-\mathrm{m}$. Maximum current electrode spacings $(\mathrm{AB} / 2)$ ranged from 40 to $100 \mathrm{~m}$, providing information to depths of about $50 \mathrm{~m}$.

Normal undisturbed curves were observed at Buildings E5282 and E5481. These stations were located in topographically low areas where the water table lies within $3 \mathrm{~m}$ of the surface.

A reasonable interpretation of the curve at Building E5440, which was centered in an open area northeast of the building, is not feasible without more historical information about the site.

TABLE A.1 Location of Centers of Stations and

- Qrientations of Electrode Arrays for Schlumberger

Electrical Depth Soundings at APG

\begin{tabular}{lcc}
\hline \multicolumn{1}{c}{ Station Center } & $\begin{array}{c}\text { Array } \\
\text { Orientation }\end{array}$ & $\begin{array}{c}\text { Maximum } \\
\text { Electrode } \\
\text { Spacing } \\
(\mathrm{m})\end{array}$ \\
\hline Northeast of Building E5282 & E-W & 50 \\
Northeast of Building E5440 & NW-SE & 40 \\
North of Building 5481 & E-W & 80 \\
Northwest of Building E5974 & NW-SE & 100 \\
\hline
\end{tabular}

\footnotetext{
* Electrical depth soundings were measured in the unit of ohm-meter. Thus, discussion of electrical depth soundings in this report gives depths measured in meters. To convert from meters to fect, multiply depths in meters by 3.28 .
} 
Former roads, landfills, and other subsurface artifacts could explain the orders of magnitude change in resistivity values from $15 \Omega-\mathrm{m}$ to $10,000 \Omega-\mathrm{m}$ at a depth of $11 \mathrm{~m}$.

The sounding curve at Building E5974 displays the most unusual surface resistivities. A 2.7-m-thick layer of extraordinarily high resistiviiy $(3,055 \Omega-\mathrm{m})$ near the surface is underlain by a layer having, a higher than normal value $(440 \Omega-\mathrm{m})$ extending to a depth of $50 \mathrm{~m}$. This is underlain by a layer having normal resistivities of $123 \Omega-\mathrm{m}$. 

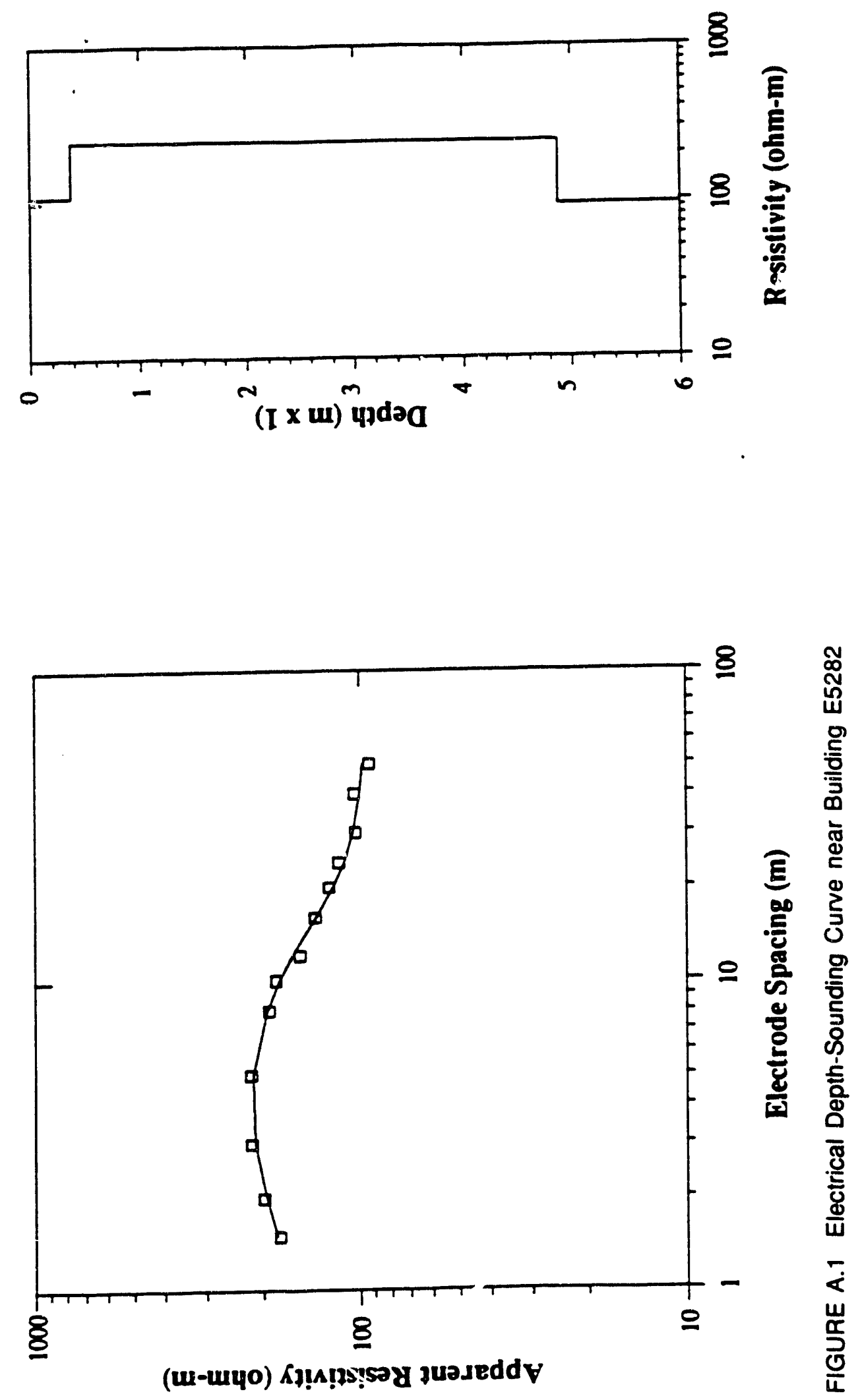


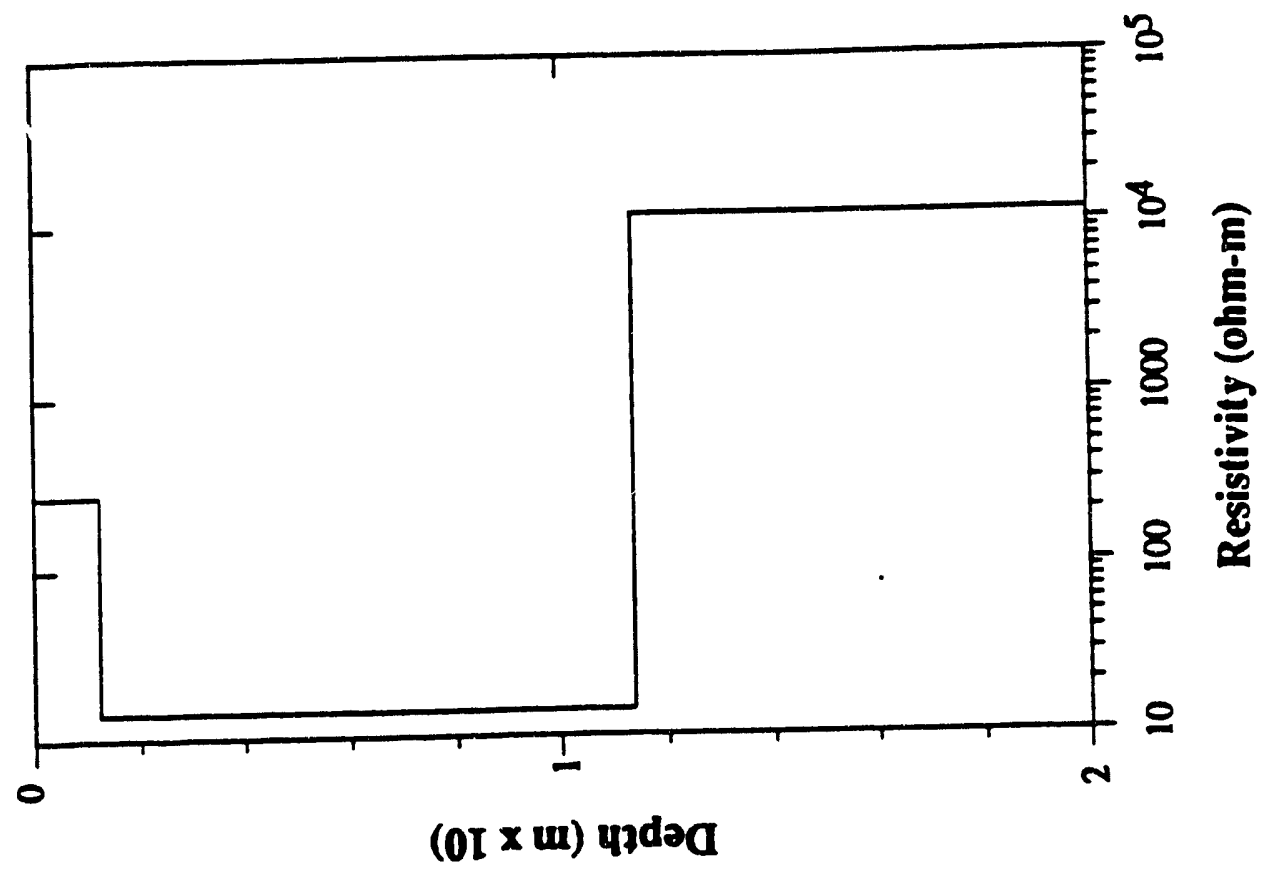

웜

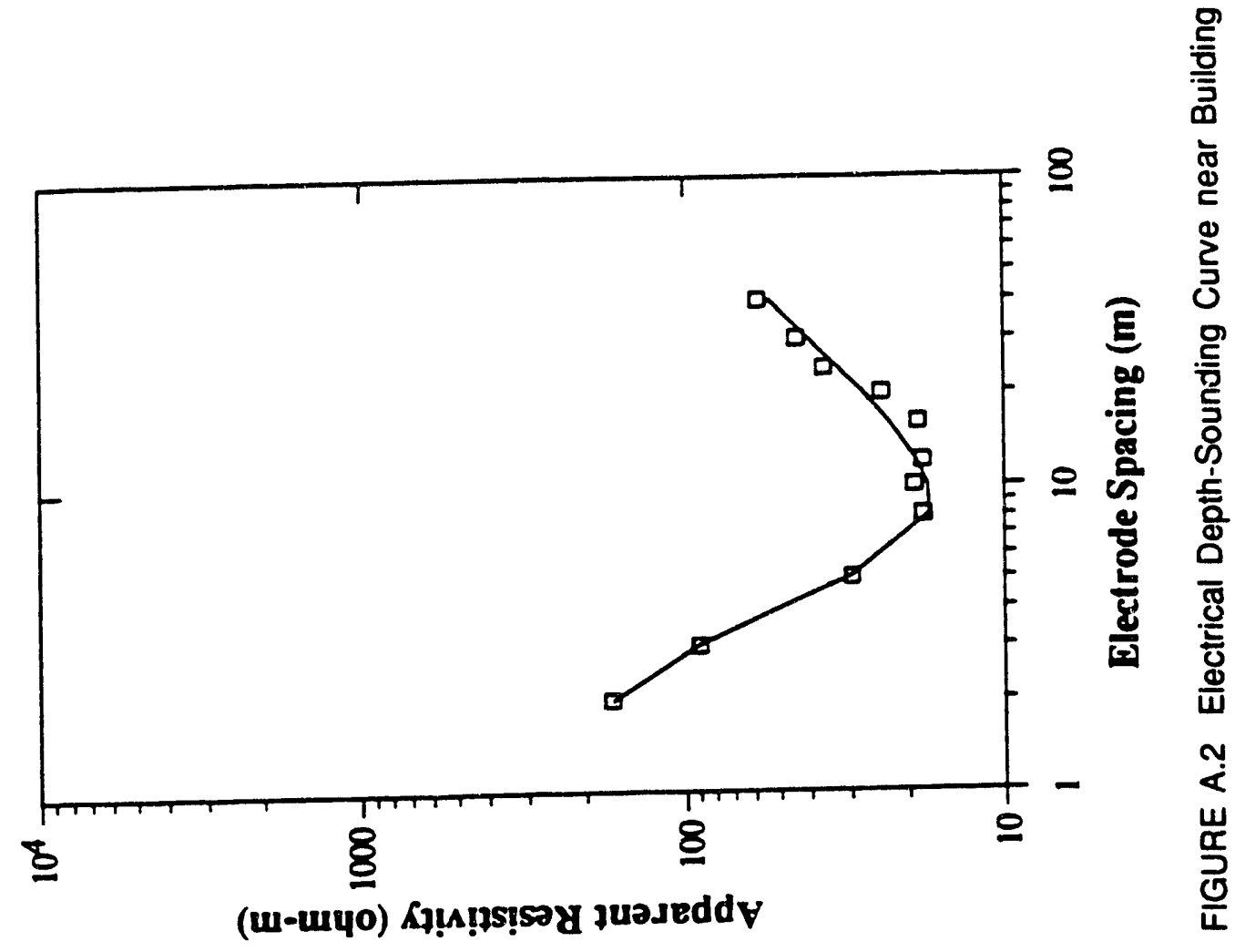



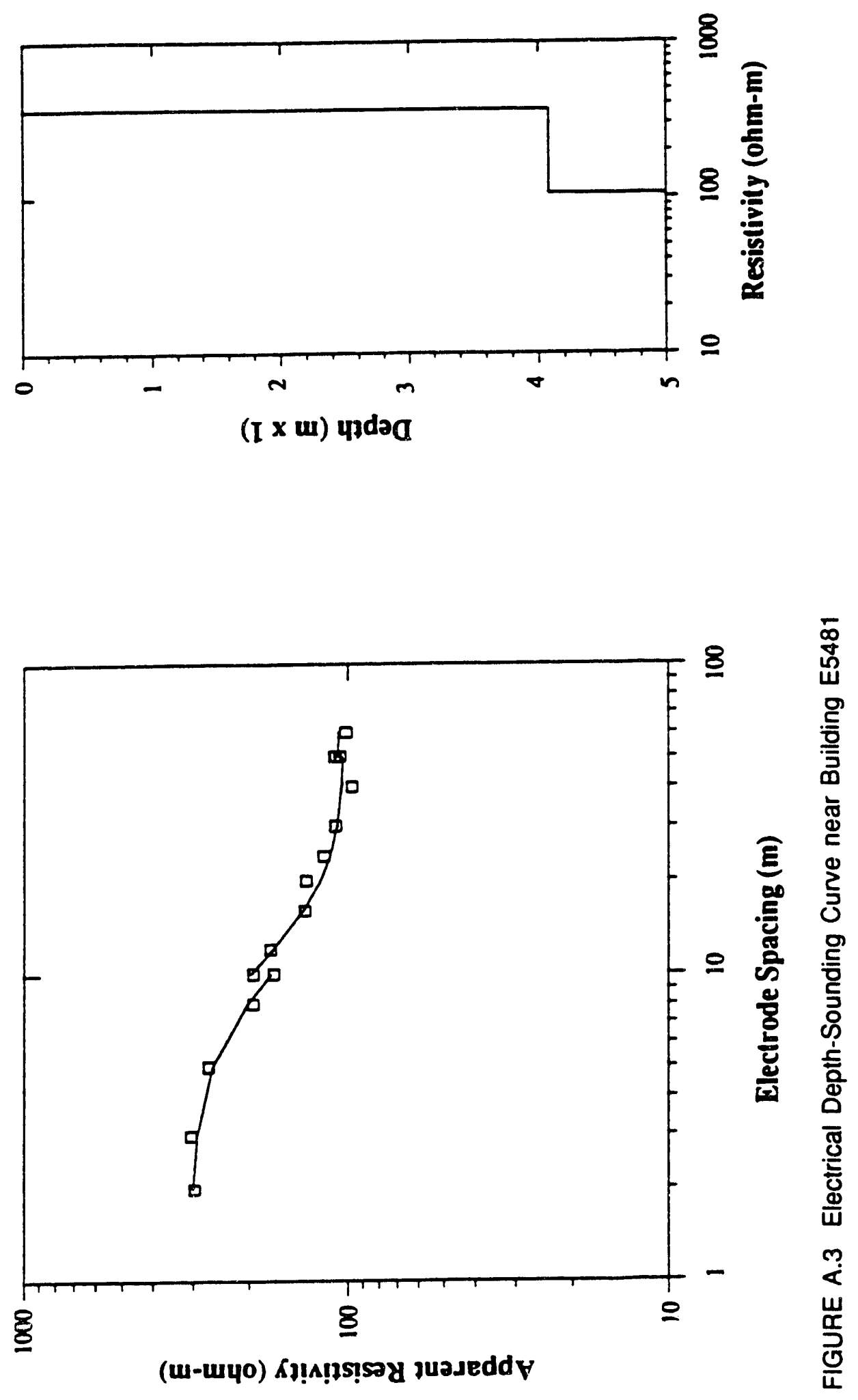

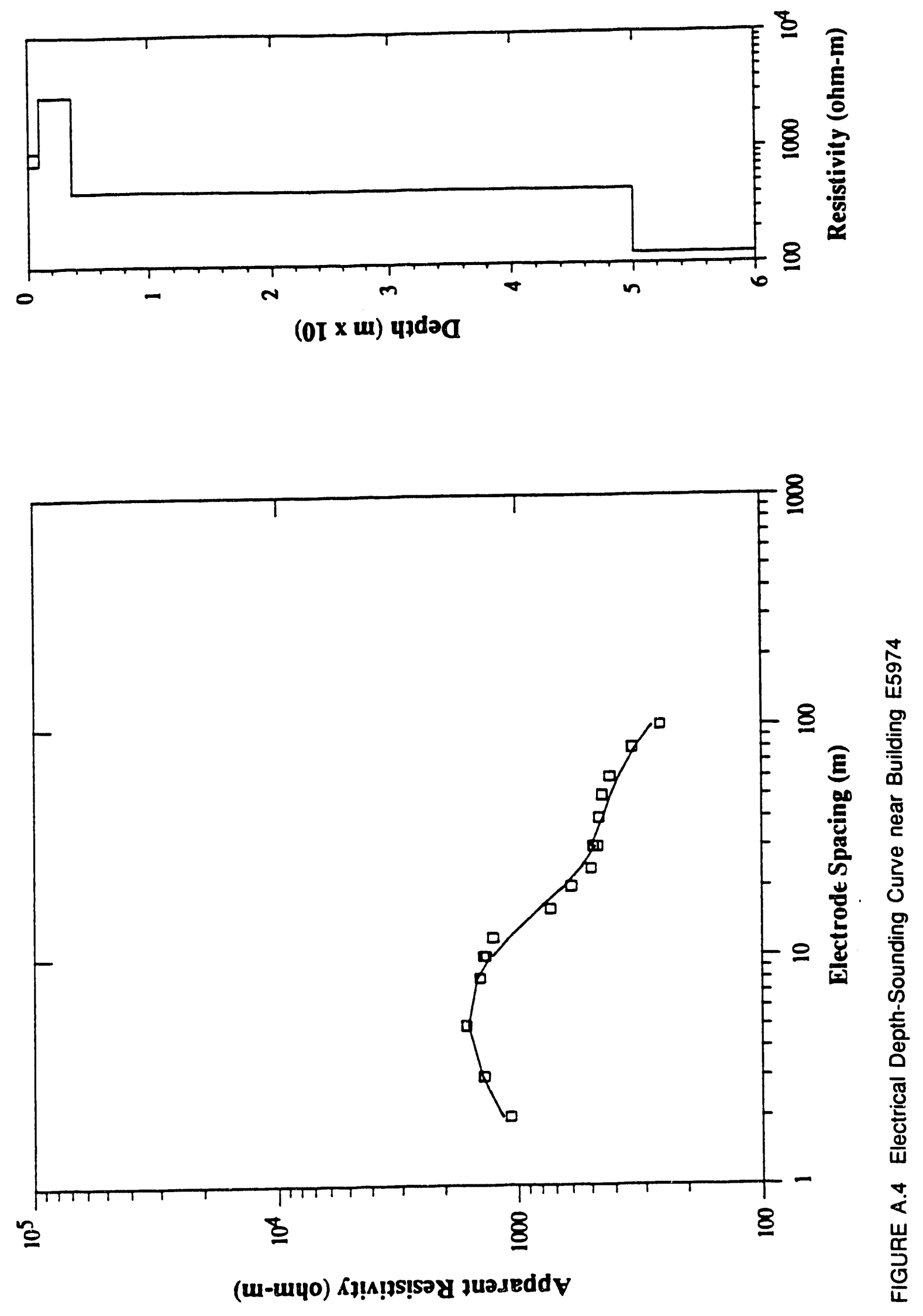
Appendix B:

Ground-Penetrating Radar Line Coordinates 


\title{
Appendix B:
}

\section{Ground-Penetrating Radar Line Coordinates}

\author{
103 Dump
}

\begin{tabular}{|c|c|c|c|c|}
\hline \multirow{2}{*}{$\begin{array}{l}\text { Line } \\
\text { No. }\end{array}$} & \multicolumn{2}{|c|}{$\begin{array}{c}\text { Start } \\
\text { Coordinates } \\
\end{array}$} & \multicolumn{2}{|c|}{$\begin{array}{c}\text { End } \\
\text { Coordinates }\end{array}$} \\
\hline & North & East & North & East \\
\hline 1 & 00 & 00 & 00 & 250 \\
\hline 2 & 20 & 00 & 20 & 250 \\
\hline 3 & 40 & 00 & 40 & 250 \\
\hline 4 & 60 & 00 & 60 & 250 \\
\hline 5 & 85 & 00 & 85 & 250 \\
\hline 6 & 100 & 00 & 100 & 250 \\
\hline 7 & 120 & 00 & 120 & 250 \\
\hline 8 & 135 & 00 & 135 & 250 \\
\hline 9 & 140 & 250 & 00 & 250 \\
\hline 10 & 140 & 230 & 00 & 230 \\
\hline 11 & 140 & 210 & 00 & 210 \\
\hline 12 & 140 & 190 & 00 & 190 \\
\hline 13 & 140 & 170 & 00 & 170 \\
\hline 14 & 140 & 150 & 00 & 150 \\
\hline 15 & 140 & 130 & 00 & 130 \\
\hline 16 & 140 & 110 & 00 & 110 \\
\hline 17 & 140 & 90 & 00 & 90 \\
\hline 18 & 140 & 70 & 00 & 70 \\
\hline 19 & 140 & 50 & 00 & 50 \\
\hline 20 & 140 & 30 & 00 & 30 \\
\hline 21 & 140 & 10 & 00 & 10 \\
\hline 22 & 140 & 00 & 00 & 00 \\
\hline 23 & 70 & 00 & 70 & 70 \\
\hline 24 & 75 & 00 & 75 & 70 \\
\hline 25 & 80 & 00 & 80 & 70 \\
\hline 26 & 85 & 00 & 85 & 70 \\
\hline 27 & 90 & 00 & 90 & 70 \\
\hline 28 & 95 & 00 & 95 & 70 \\
\hline 29 & 100 & 00 & 100 & 70 \\
\hline
\end{tabular}



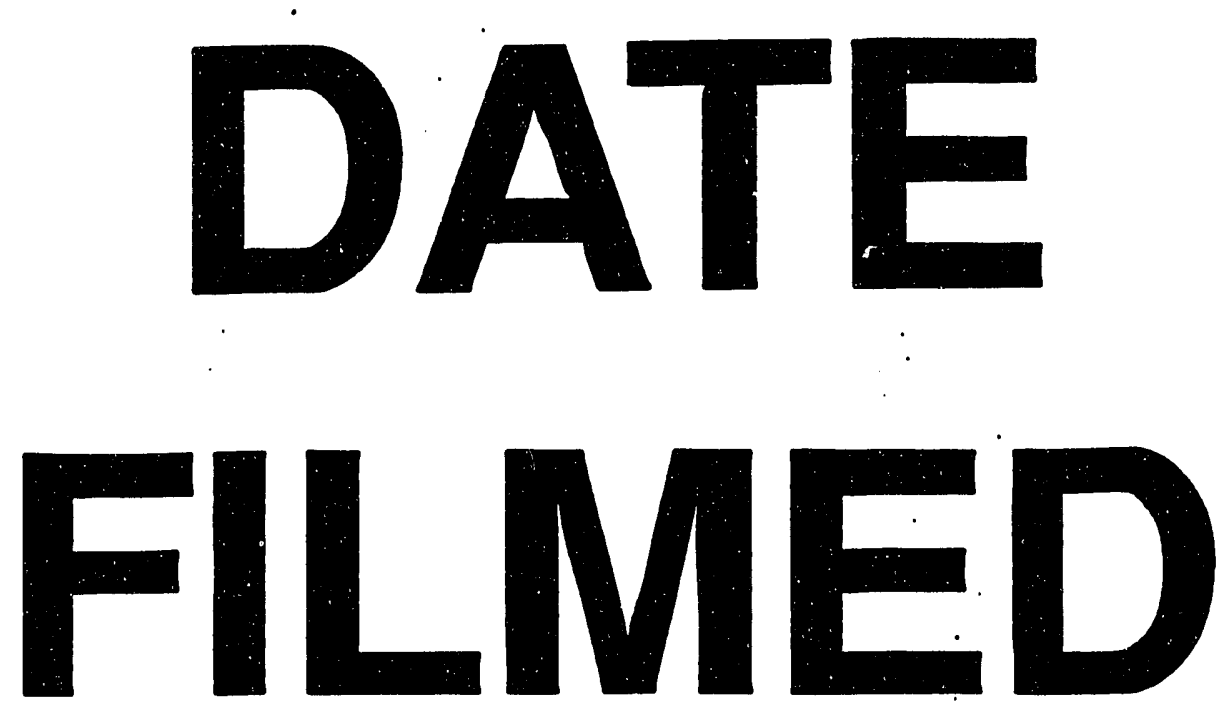

$10 / / 4 / 93$
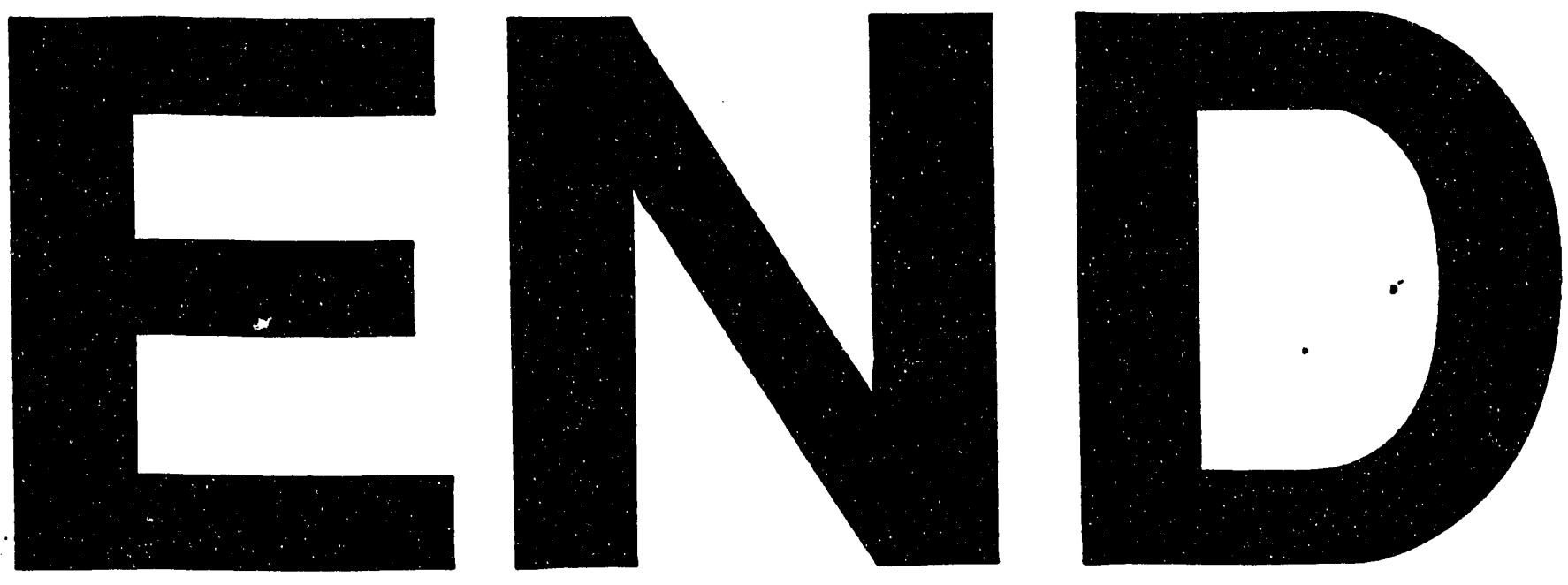
